القدرات العقلية اللازهمة لأداء عملية تصميم الأزياء

\author{
إعلاد \\ م/ رباب حسر م محمد \\ أستاذ مساعد بقسم الملابس والنسيج \\ كلية الاقتصاد المنزلي جامعة حلوان
}

مجلة بحوث التربية النوعية ـ جامعة المنصورة

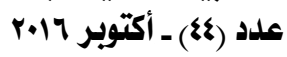




\title{
القدرات العقلية اللازهة لأداء عملية تصميم الأزياء
}

\author{
إعداد \\ د/رباب حسنمحمد
}

\section{هلخص البمث}

يهدف البحث الى:

• تحديد القدرات العقلية اللازمهة للقائم بعملية تصميم الأزياء.

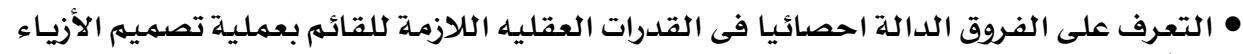

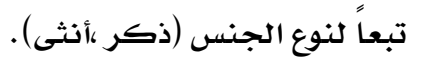

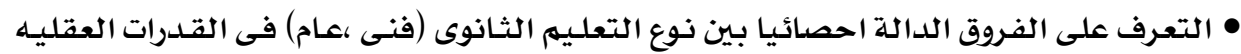

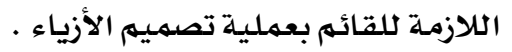

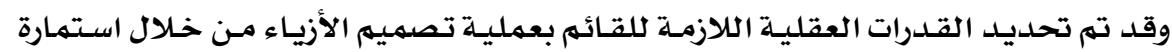

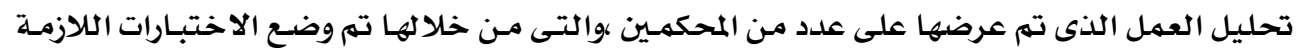

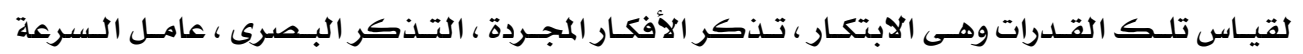

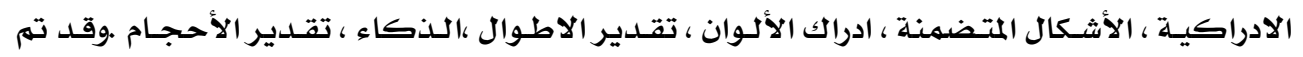

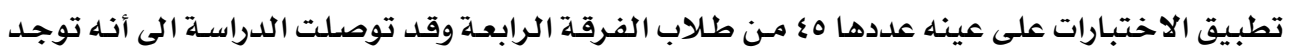

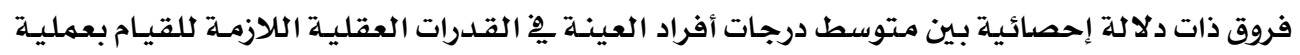

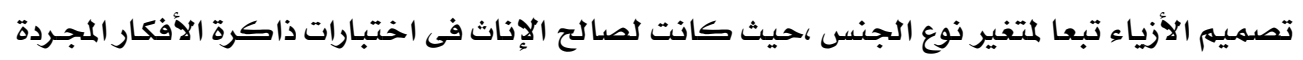

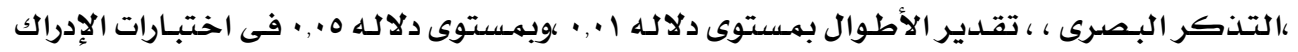

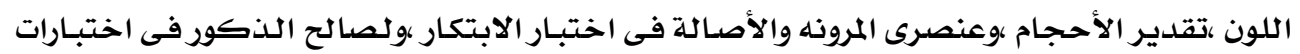

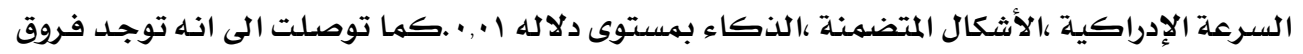

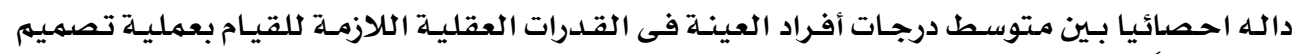

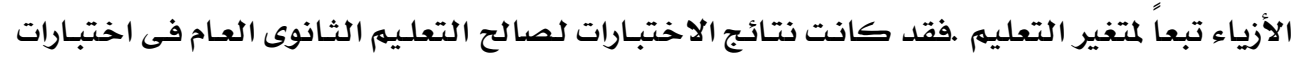

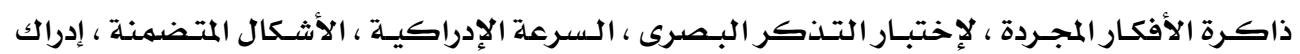

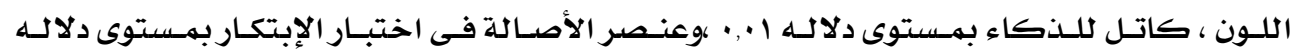

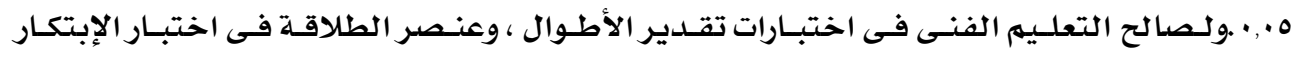

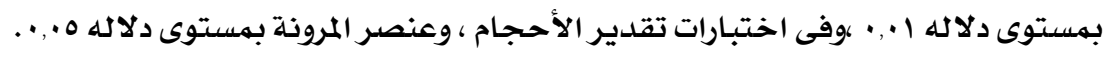

• أستاذ مساعد بقسم الملابس والنسيج- كلية الإقتصاد المنزلى جامعة حلوان 
يعد الاهتمام بالعقل البشرى وأساليب نموه وتطوره من أهم اهتمامات المجتمعات في الوقت الراهن،فتقدم المجتمع ورقيـه يتوقف بدرجـة كبيرة على تطور القدرات ،والكفـاءات العقليـة لأفرادهـا

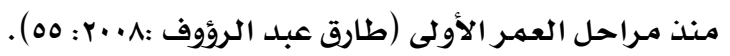

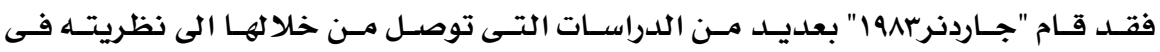

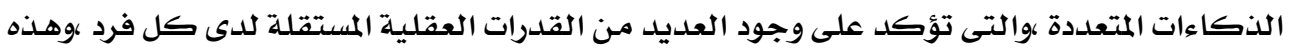

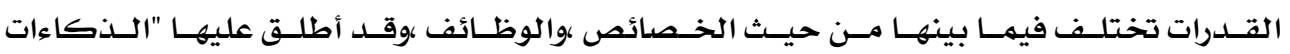

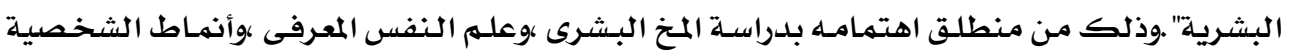

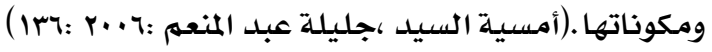

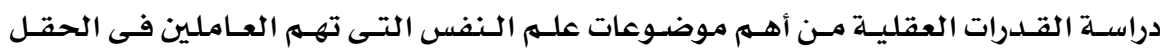

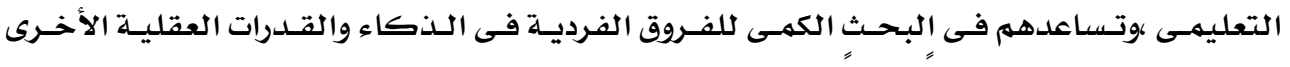

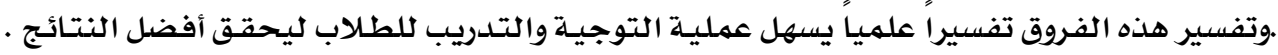

(

لذا تشترط بعض الكليات مثل كليات الفنـون الجميلـة والتربيـة الفنيـة والتربيـة الرياضيـة

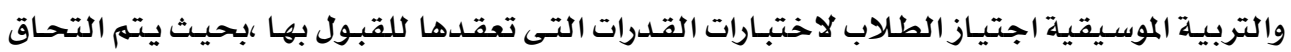

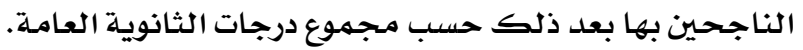

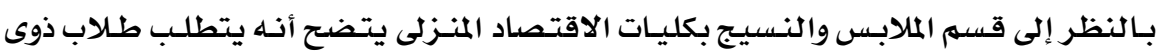

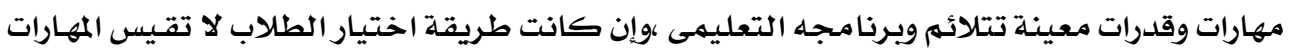

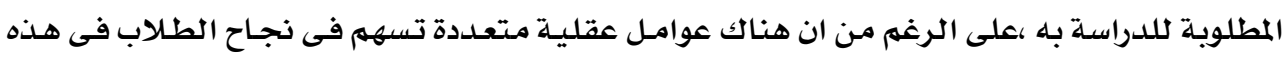

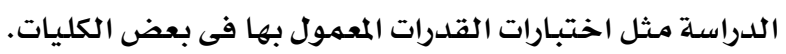

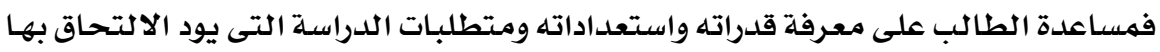

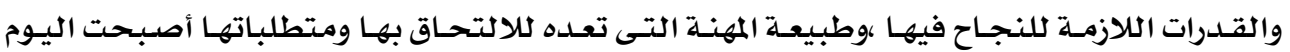

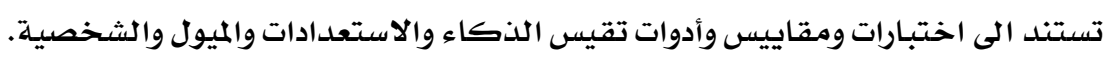

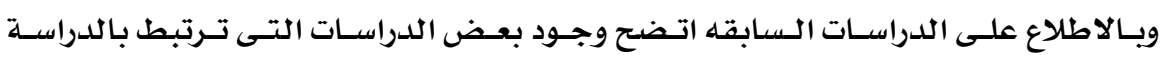

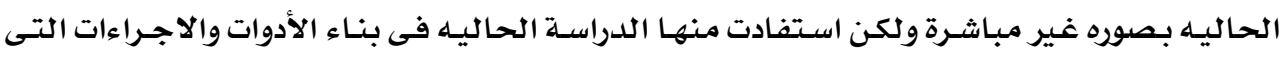

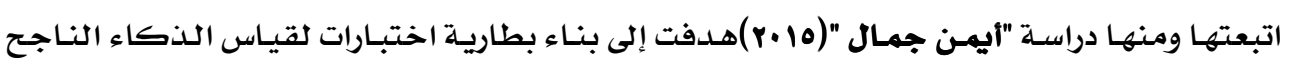

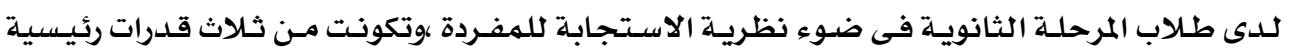

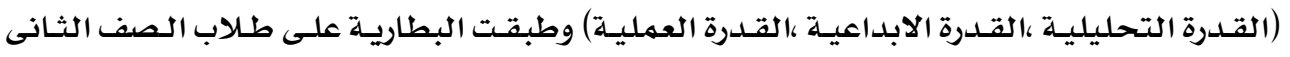

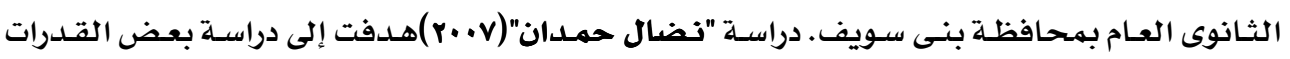

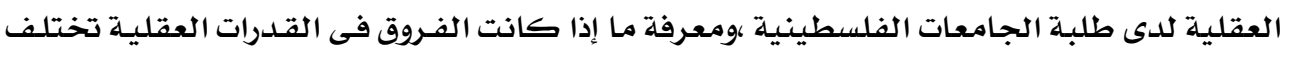

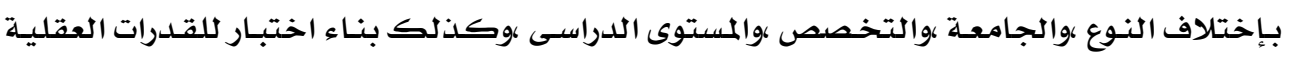

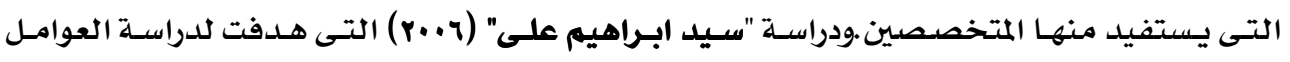




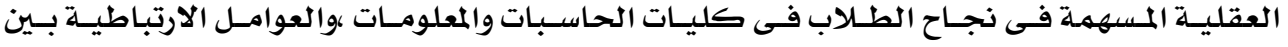

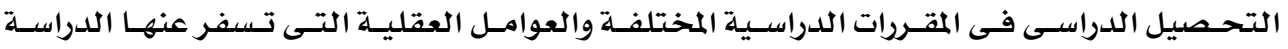

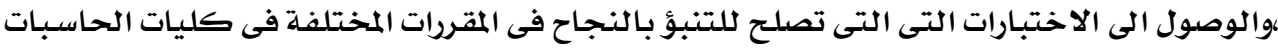

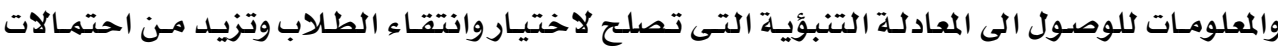

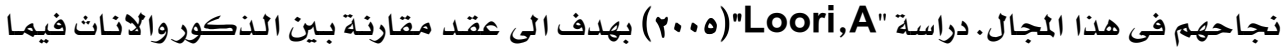

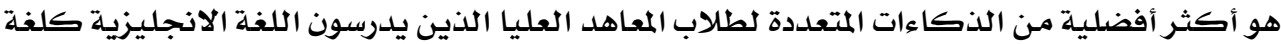

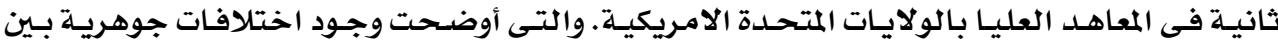

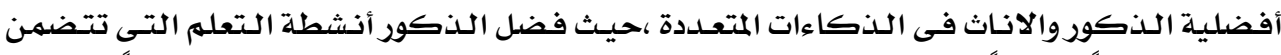

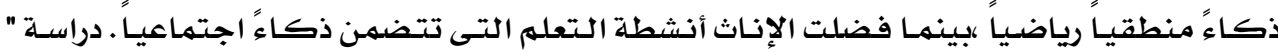

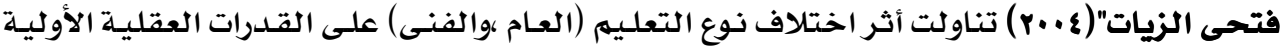

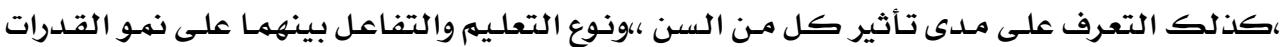

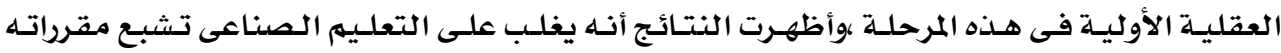

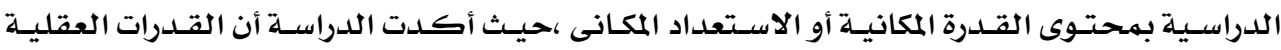

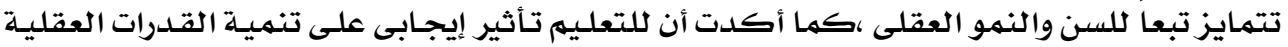

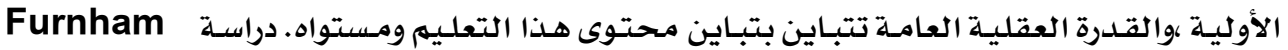

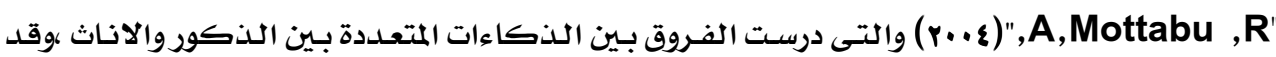

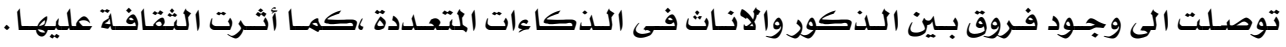

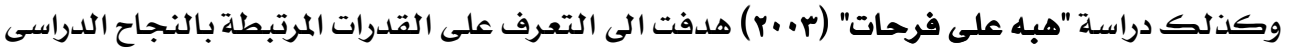

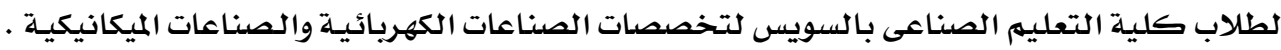

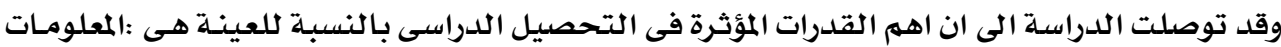

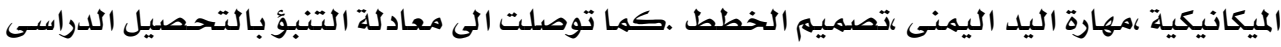

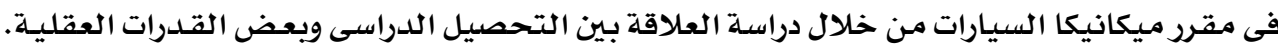

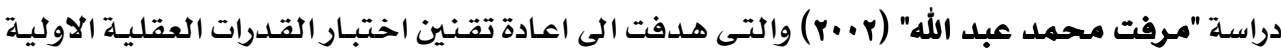

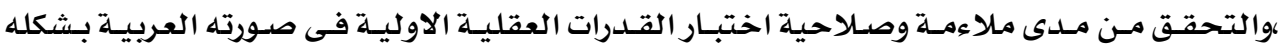

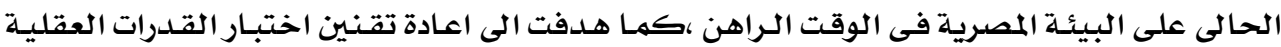

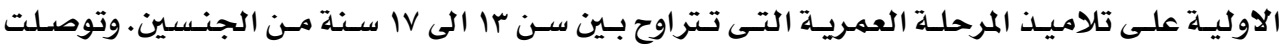

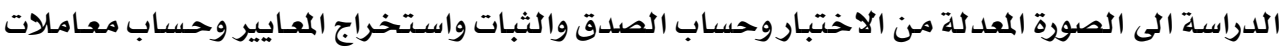

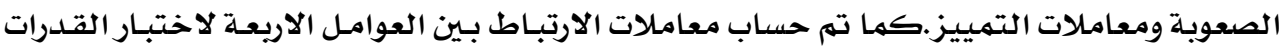

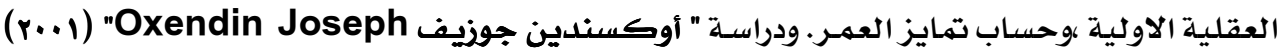

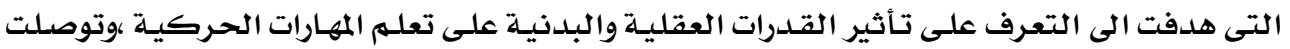

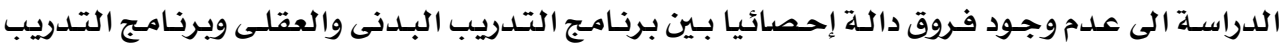

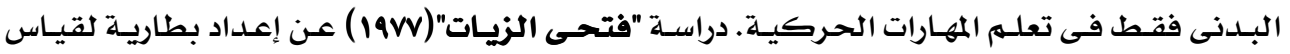

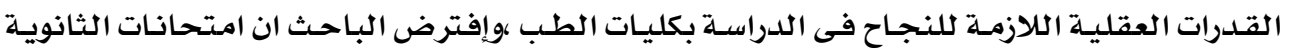


العامـة لا تصلح بمفردها التنبؤ بالنجاح فى الدراسة بكليات الطب ،وتوصلت الدراسـة إلى التحقق مـن

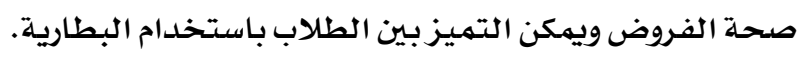

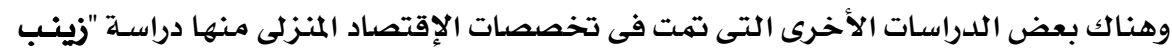
عبد الحفيظ ،نجوى شكرى"(1990) التى هدفت الى تحديد القدرات العقلية التلازمة لعملية التهي التشكيل

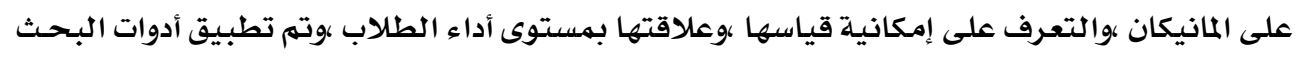

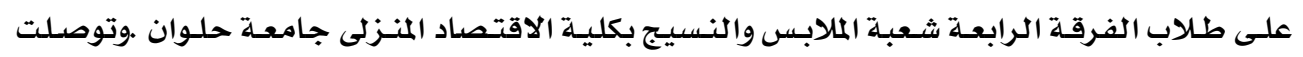

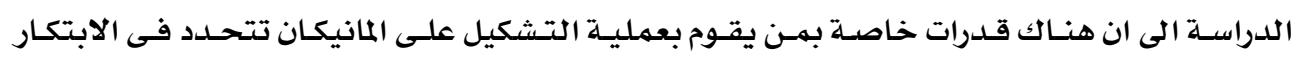

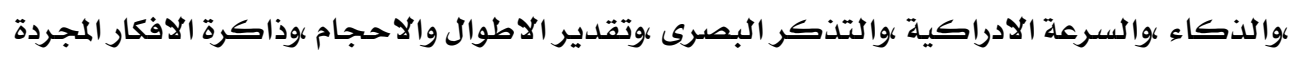

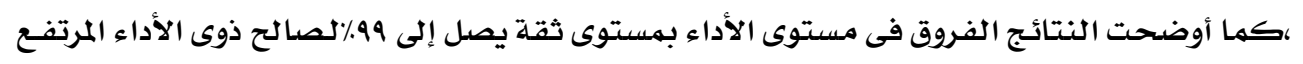

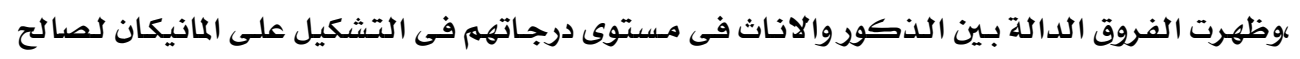

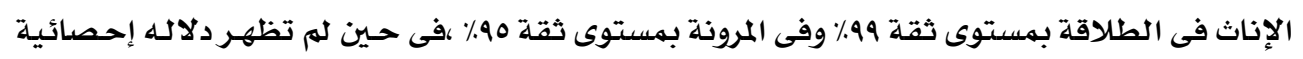

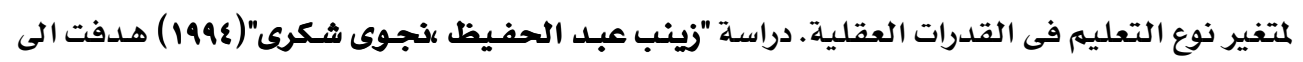

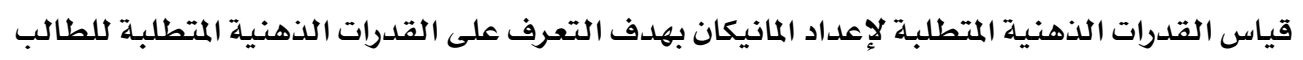

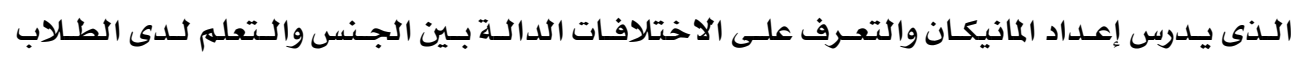

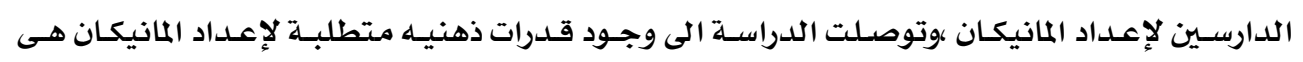

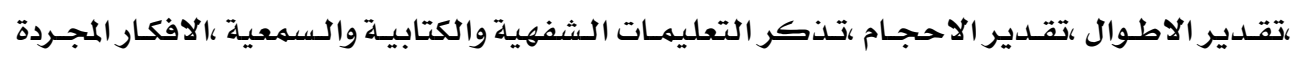

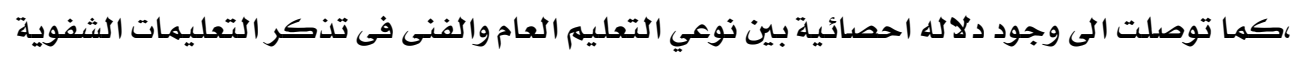

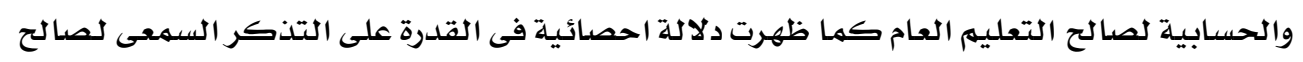

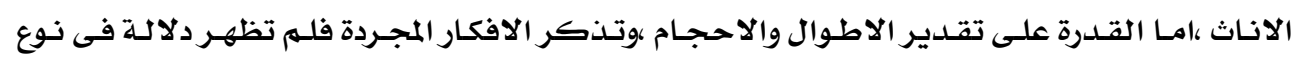

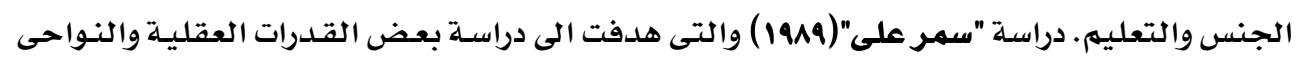

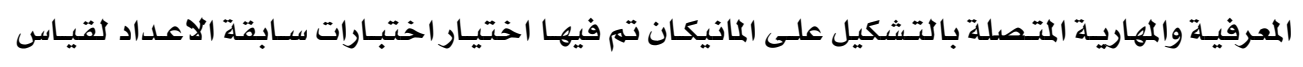

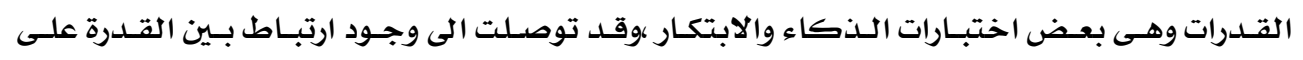

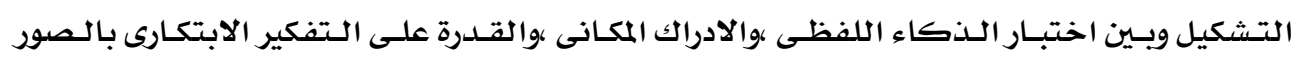

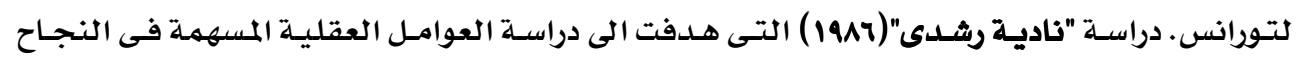

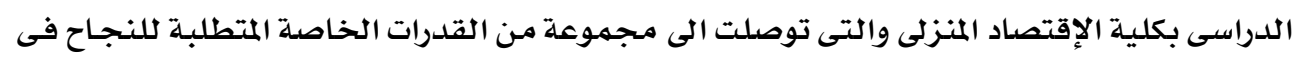

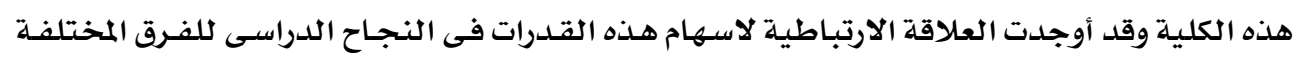
بالنسبة للشعبة التربوية.

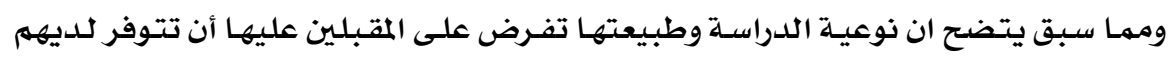

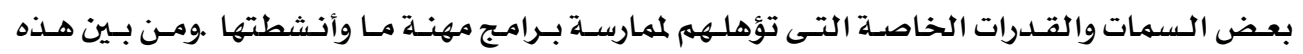

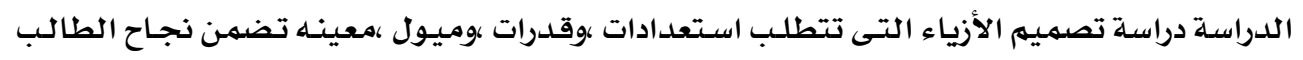

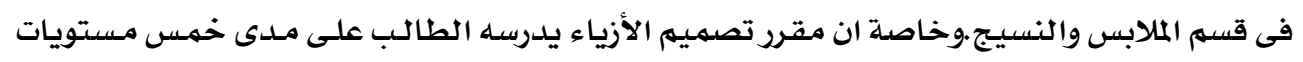

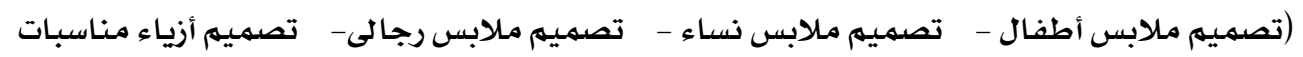

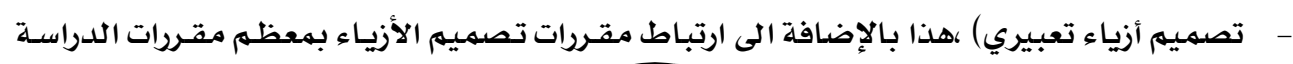




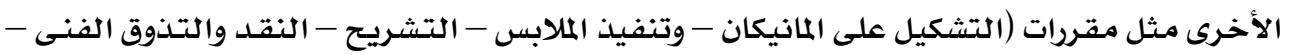

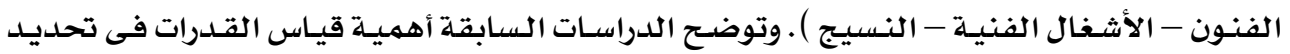

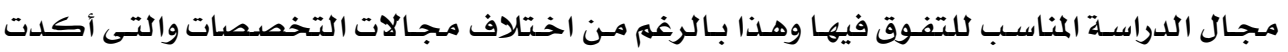

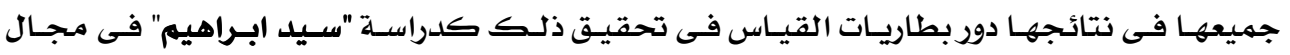

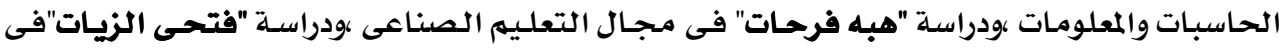

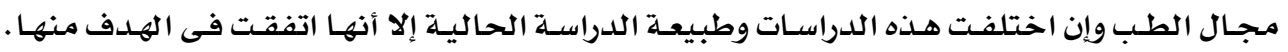

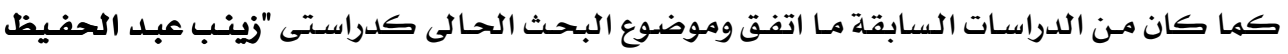

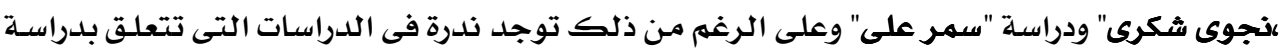

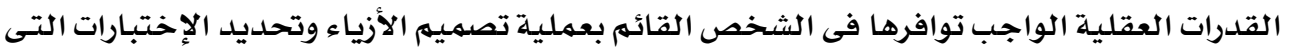

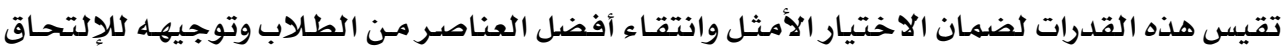

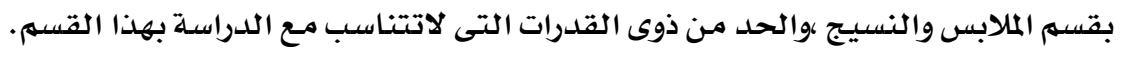

\section{وتبرز مشكلة البحث فى التساؤلات التالية:-}

ا ـ ما هى القدرات العقلية اللازمهة للقائم بعملية تصميم الأزياء؟

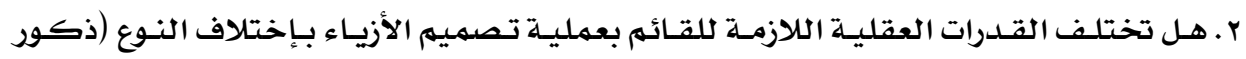
؟ إناث

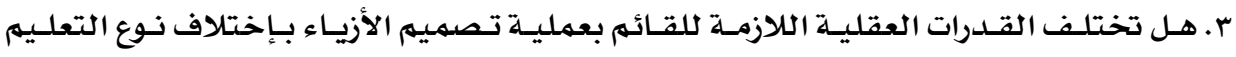

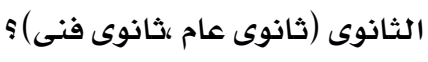

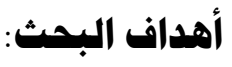

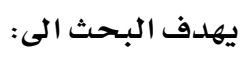

ا ـ تحديد القدرات العقلية اللازمـة للقائم بعملية تصميم الأزياء.

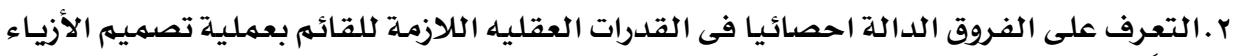

$$
\text { تبعاً لنوع الجنس (ذبكر التفرو أنثى). }
$$

r.التعرف على الفروق الدالة احصائيا بين نوع التعليه الثانوى (فنى ،عام) فى القـدرات العقليـه

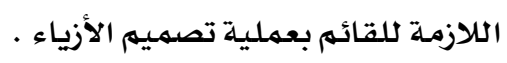

ا. القـاء الضوء على بعص العوامـل العقليـة التى تلعبب دورا اسـاسـيا فى نجـاح الطلاب فى قسمى

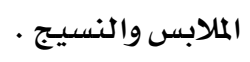

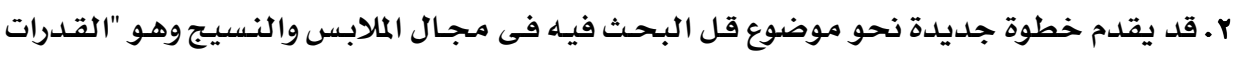

$$
\text { العقلية "والعمل على دراسته والتطرق اليهله. }
$$

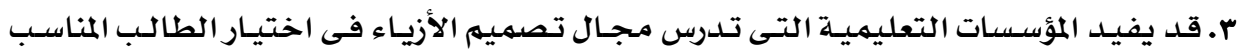

$$
\text { وكيفية تنمية وتطوير قدراته العقلية. }
$$




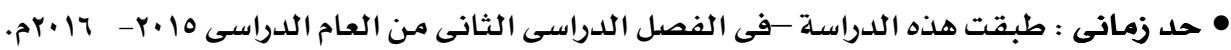

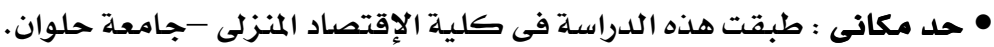

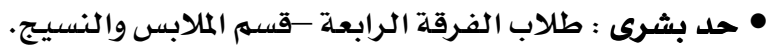

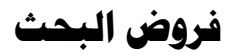

ا ـ توجد فروق داله احصائيا بـين متوسط درجات أفراد العينة فى القـدرات العقليـة اللازمـة للقيـام

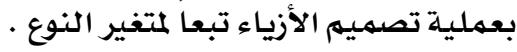

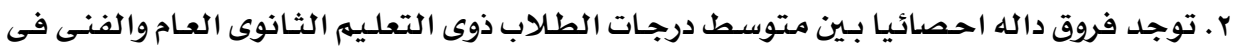

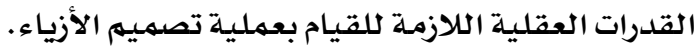
مصطات البمث البدرات

•

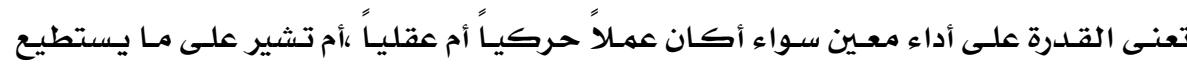

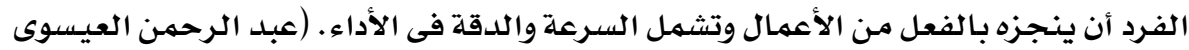

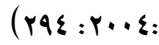

- هى قوة متوفرة لدى الشخص ،تمكنه من أداء فعل معين سواء كان نشاط حركى أو عقلى ،

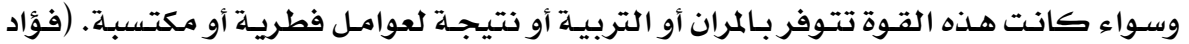

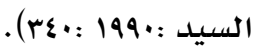

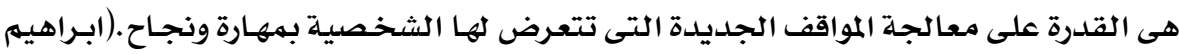

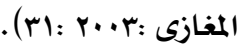

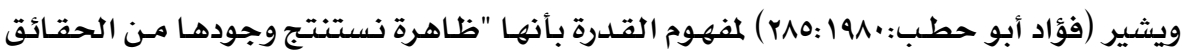
التى يمكن ملاحظتها مباشرة بحكم أنها أسلوب من أساليب الأداء القابلة للقياس.

Mental Ability : القدرة العقلية ماحسية

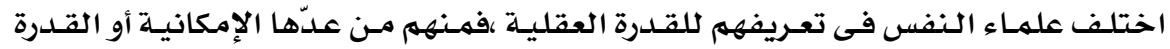

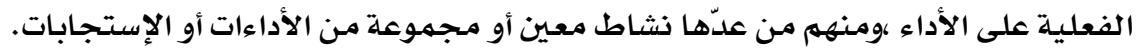

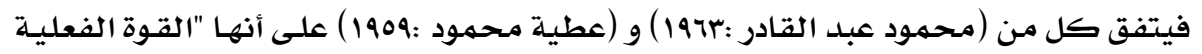

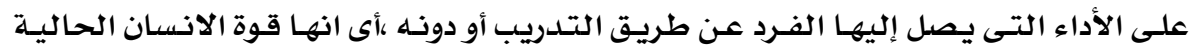

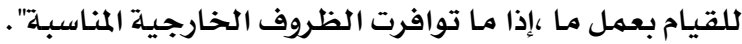

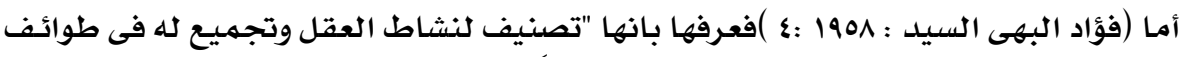

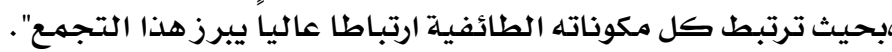

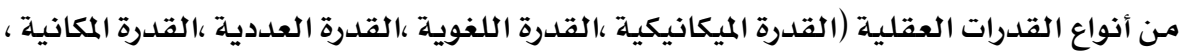

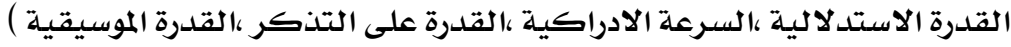


ويعرفها (فؤاد أبو حطب :199r :11r) بأنها "نوع مـن التكوينـات الفرضية نشتقه أو نستتنجها

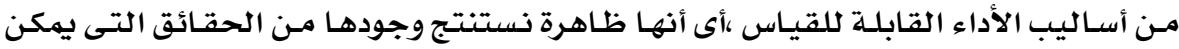
ملاحظتها ملاحظة مباشرة .

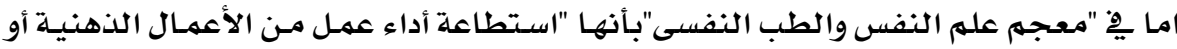

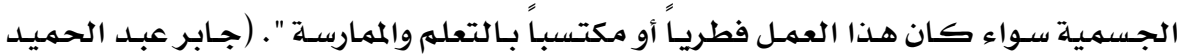

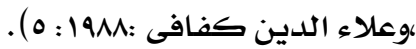

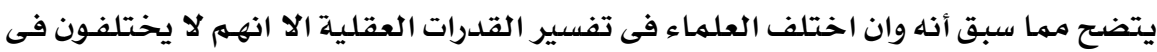

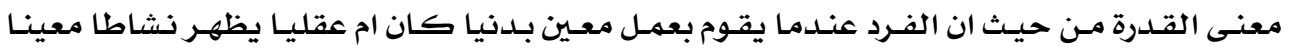

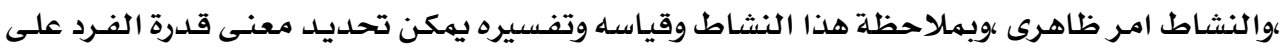

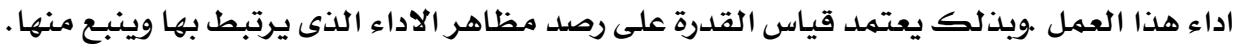

\section{• تصميم الأزياء: Fashion design}

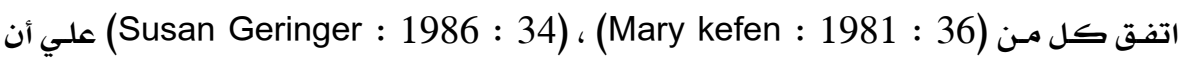

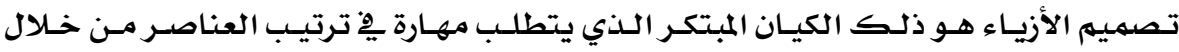

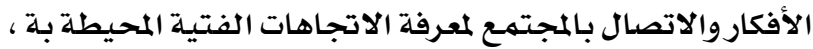

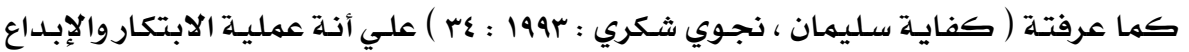

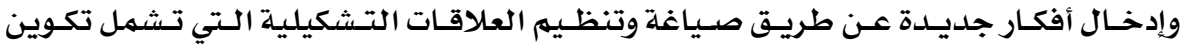

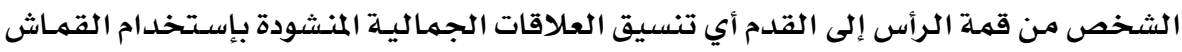

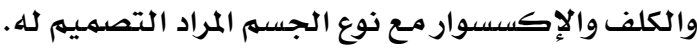

يتبع هذا البحث المنهج الوصفى التحليلى لتحقيق أهداف البحث والتحقق من فروضه.
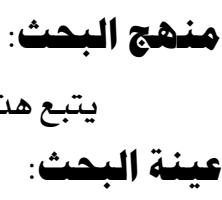

تكونت عينة البحث من طلاب الفرقة الرابعة شعبـة الملابس والنسيج بكلية الاقتصاد المنزلى

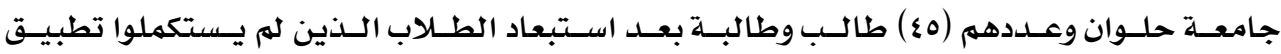

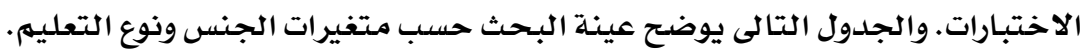
جدول رقم (1) توزيع عينة البحث

\begin{tabular}{|c|c|c|c|c|c|}
\hline النسبة.| & العدد & نوع التعليم الثانوى & النسبة| & العلد & الجنس \\
\hline$\% r v, \Lambda$ & iv & عام & $\%$ Y & 11 & ذكور \\
\hline$\%$ \% r, & $r \Lambda$ & قنى & $\%$ Yo, 7 & TE & الاناث \\
\hline$\%$ & $\leqslant 0$ & المجموع & $\%$ & 80 & المجمهوع \\
\hline
\end{tabular}

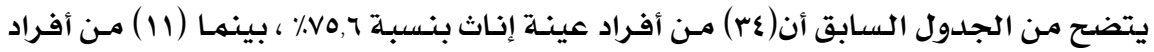

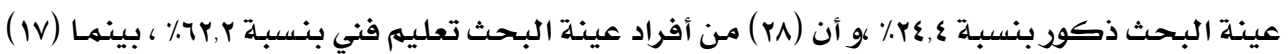

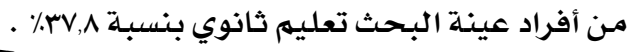


من أجل تحقيق أهداف البحث قامت الباحثة بإجراء الخطوات التالية:

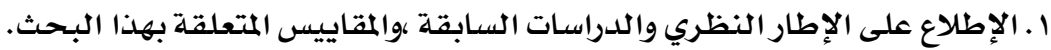

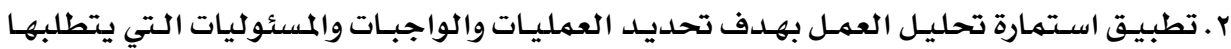
تصميم الأزياء ،وكذلك قدرات وسمات الشخص القائم بعملية التصميهم ببالإضافة إلى المكان

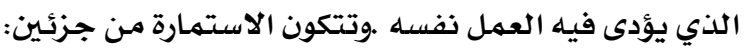
- الجزء الأول ' :يتضمن وصف العمل نفمل من يقوم بعملية تصميهم الأزياء.

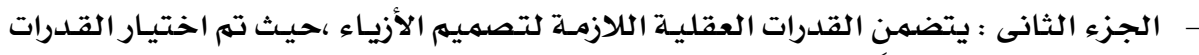

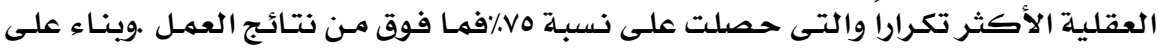
ذلك تم تحديد الاختبارات المناسبة لقياس القدرات.

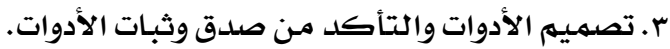

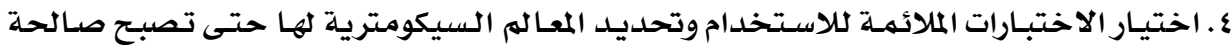

$$
\text { ه . تطبيق الاختبارات على البحث الحالي. }
$$

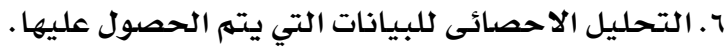

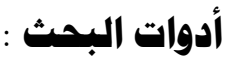

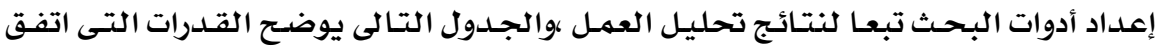

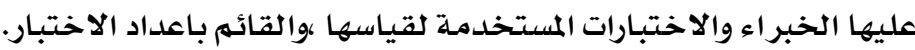

\begin{tabular}{|c|c|c|}
\hline اسم معد الاختبار & نوع الاختبار & القدرات \\
\hline الباحثة & القدرة على الابتكار & الابتكار \\
\hline كاتل & القدرات العقلية & الذكاs \\
\hline زينب عبد الحفيظ ، نجوى شكرى & القدرة على تقدير الحجي & تقدير الأحجام \\
\hline الباحثة & أقصر طول & تقدير الأطوال \\
\hline الباحثة & القدرة على التذكر البصرى & التذكر البصرى \\
\hline سليمان الخضرى واّخروز & اختبار عامل السرعة الادراكية & \multirow{3}{*}{ القدرة الادراكية } \\
\hline انور الشرقاوى وآخرون & الاشكال المتضمنه & \\
\hline الباحثة & الادراك اللونى & \\
\hline الباحثة & القدرة على تذكر الافكار & ذاكرة الافكار المجردة \\
\hline
\end{tabular}
جدول رقم (r) الاختبارات المستخدمة لقياس القدرات

1 استمارة تحليل العمل ونتائج الجزء الأول ملحق رقمى (؟) 
أولا:اختبار تذكر الأفكار المجردة (من أعداد الباحثة) "مأخوذ عن زينب عبد الحفيظ ، نجوى شكرى"

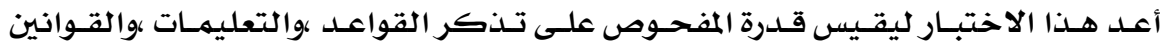

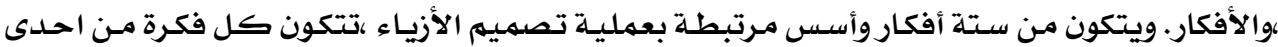

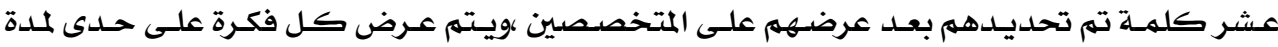

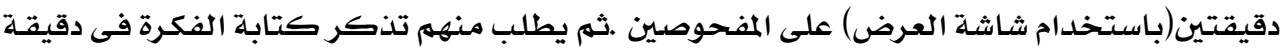

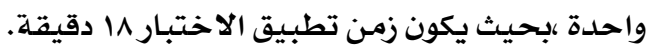
تصحيح الإختبار:

تعطى درجـة واحسدة لكل فكـرة يتـذكرها المفحسوص ثم درجـة واحسدة لكل كلمهـة يتـذكرها

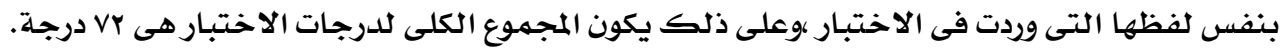

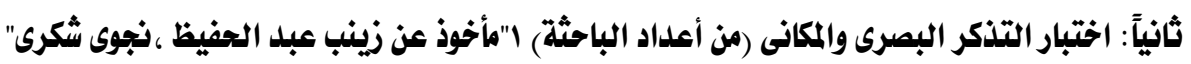

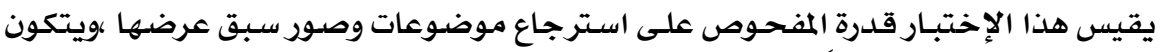

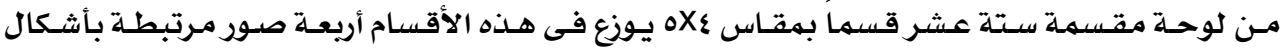

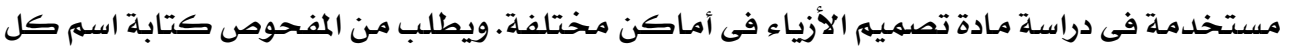

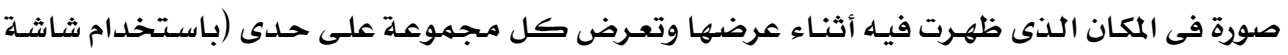
العرض) المدة ثلاث ثوان شثم يعطى للمفحوص المثل فلاث ثوان أخرى للكتابة.

تصحيح الإختبار:

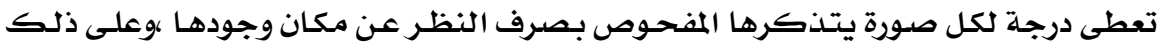

$$
\begin{aligned}
& \text { تكون الدرجة الكلية للاختبار (7ادرجة) . }
\end{aligned}
$$

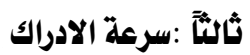

وتقاس سرعة الادراك من خلال:

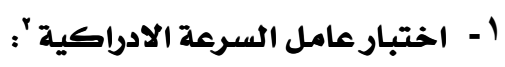

وهـو مسن إعداد (اكستروم ،فرنث ،هارمـان ،ديرمـين) وقام بتعريبـه وتقنينـه أنور الشرقاوى

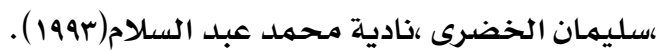
ويهدف الاختبار الى قياس سرعة الطالب فى إيجاد الاشكال وإجراء المقارنات ،واداء الاعمال

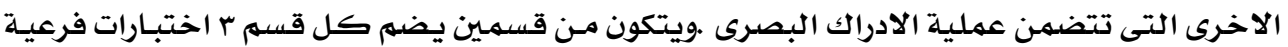

- اختبار شطب الكلمات : وملدته دقيقتان ،وبلغ معامل الثبات 070, بطريقة سبيرمان- براون.

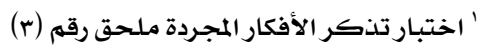

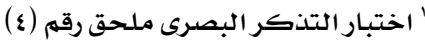

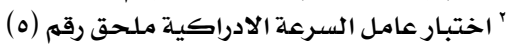


- اختبـار مقارنـة الاعداد : ومدتـه دقيقـة ونصف ،وبلـغ معامـل الثبـات 7097, بطريقـة سبيرمان-

براون.

- اختبـار الصور المتهماثلـة :ومدتـه دقيقـة ونصف ،وبلـغ معامـل الثبـات VاT, بطريقـة سبيرمان-

براون.

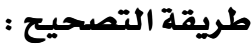

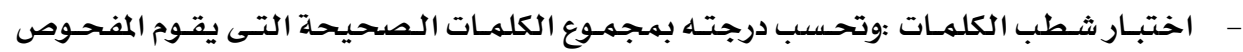

$$
\text { بشطبها فى الوقت المحدد. }
$$

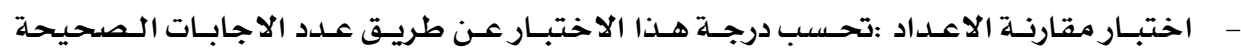

مخحصوما منها عدد الاجابات الخاطئة.

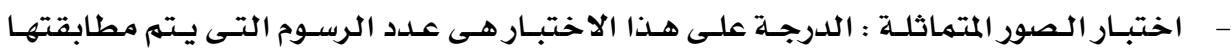

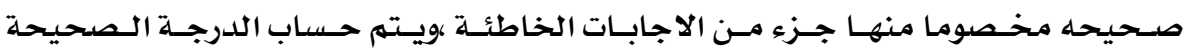

\section{عيدا الإبابات الخاءئلة}

كالأتى:

$$
\begin{aligned}
& \text { علدد الاجابات الصحيحمة - } 1 \text { - }
\end{aligned}
$$

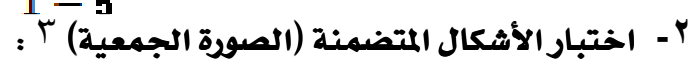

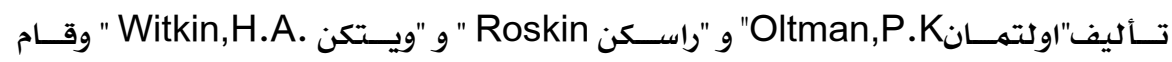

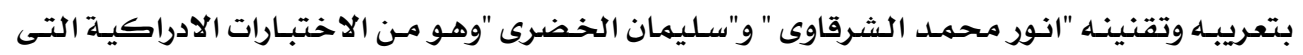

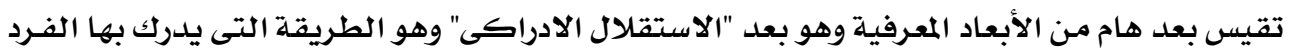

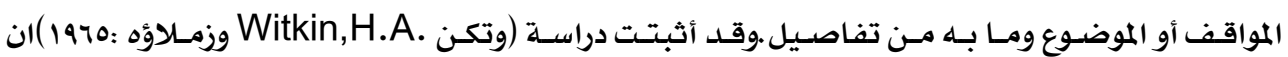
الافراد اللـديهم استقلال ادراكى يظهرون مـيلا الى التحليـل والتجريـد ويفهمون الجسهم بشكل عـام

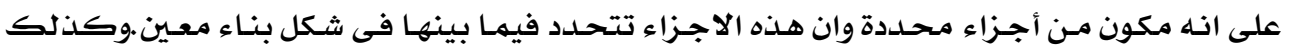
دراسـة (سـامى أبو بيـه :rی19 ) ان الاطفال الذين لديهم استقلاءل ادراكى يتميزون بـالقدرة على تناسـق

$$
\text { الرسوم المنظورة في الفراغ. }
$$

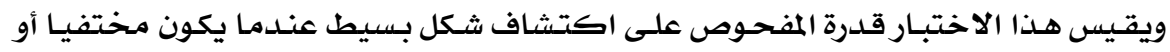
متوازيا فى شكل أكثر تعقيدا ،ويتكون من ثلاثثة أقسسام رئيسيـة هي : - القسم الاول : وهو قسهم للتدريب ،ولا تحتسب درجته فى تقدير المفحوص ويتكون مـ V فقرات

$$
\text { وزمنـه دقيقتان. }
$$

- التسمى الثانى : ويتكون من تسع فقرات متدرجـة فى صعوبتها ،والزمن المحلدد لله (0 دقائق). - القسهم الثالث : ويتكون من تسع فقرات متدرجة فى الصعوبة ، والزمن المحلدد له (ه دقائق) . وكل فقـرة مـن الفقـرات فـى الاجـزاء الثلاثلة عبـارة عن شـكل معقـد يتضهـن داخلـه شـكلا بسيطا معينا ،ويطلب من المفحوص أن يحدد بالقله الرصاص حلدود هذا الشكل البسسيط ،وقد طبعت فئ

" اختبار الأشكال المتضمنة (الصورة الجمعية) ملحق رقم ( ) 


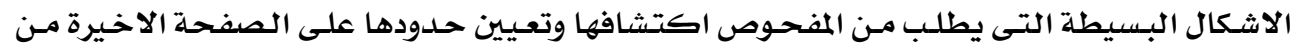

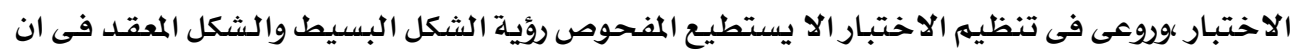

طريقة التصحيح :

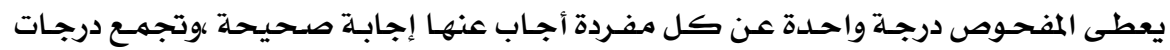

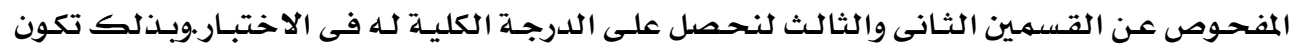

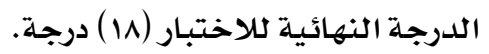
ثبات الاختبار:

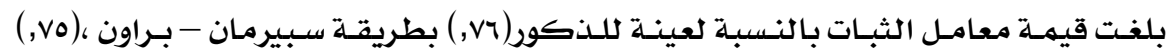

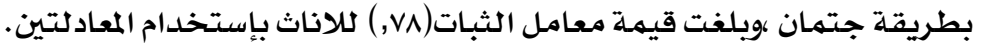
"ا- ادراك الألوان ' : (للباحثة) (مأخوذ القسم الثانى من اختبارات العمى اللونى)

$$
\text { ويتكون الاختبار من قسمـين : }
$$

• القسهم الاول :يتكون من ثمانيـة مفـردات كل مفردة تحتوى على اربعـة صـور بمجموعات لونيـه

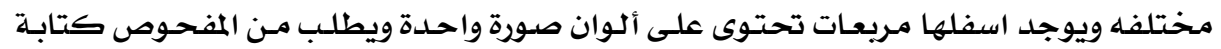

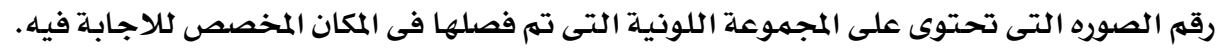
• القسهم الثانى :يتكون من خمس مفردات كل مفردة تحتوى على رقمم مكتوب بلون مغـاير للون

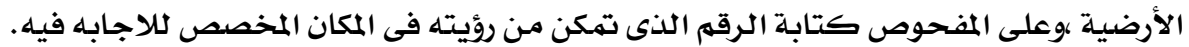

\section{طريقة التصحيح :}

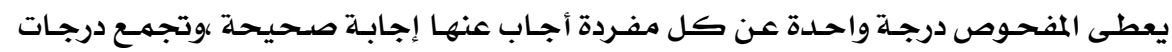

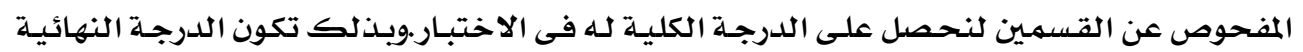
كلاختبار (rا ) درجة. ثالثا :تقدير الاطوال : اختبار اقصر طول ' : (للباحثة) "مأخوذ عن زينب عبد الحفيظ ،نجوى ثكرى"

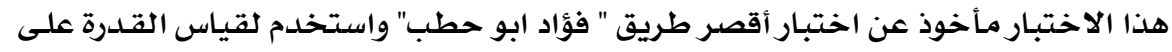

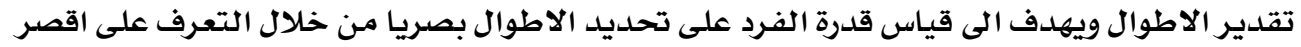

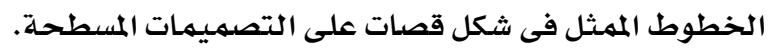


ويتكون الاختبار من ( • )سؤال ،كل سؤال مكون مـن تصميم مسطح مـرسوم عليـه قصتان

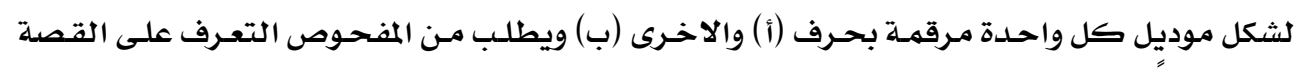

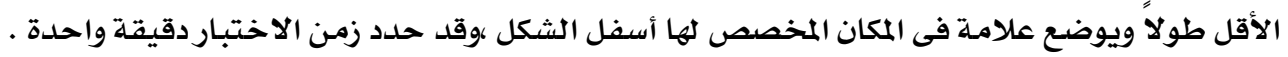

\section{طريقة التصحيح:}

يحسب درجة واحدة لكل اجابه صحيحة وبذلك الدرجة الكلية للاختبار هى ·r درجة.

رابعا :اختبار الذكاء

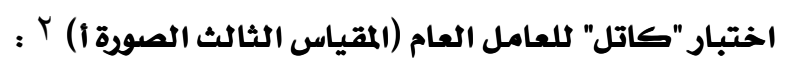

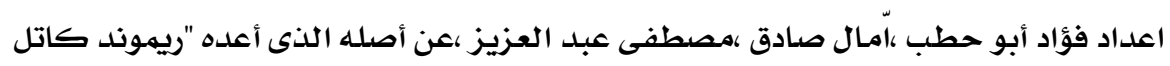

$$
\text { R.Cattel }
$$

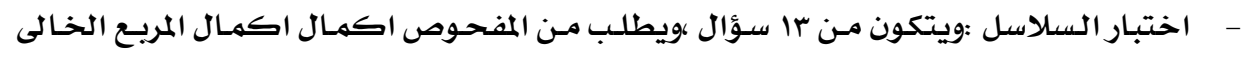

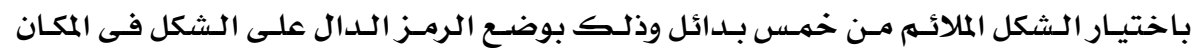

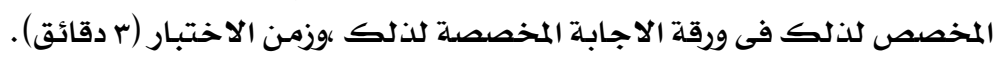

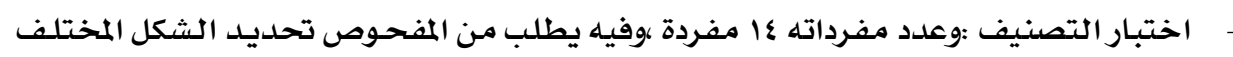

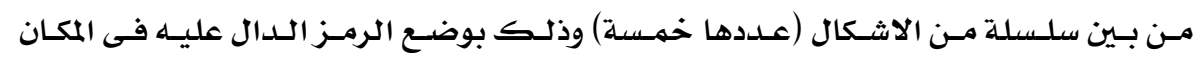

$$
\text { المخصص لذلك ،وزمن الاختبار (ع دقائق). }
$$

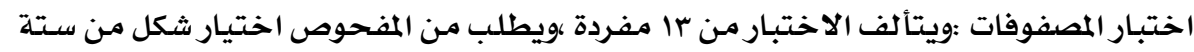

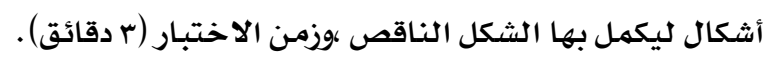

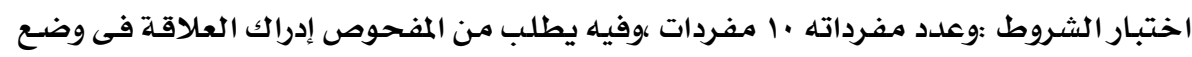

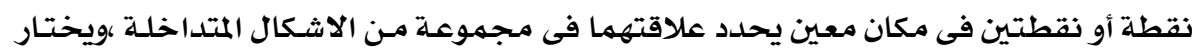

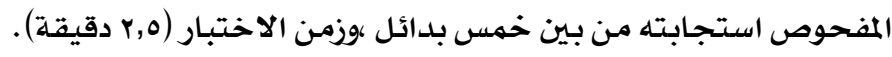

\section{ثبات الاختبار:}

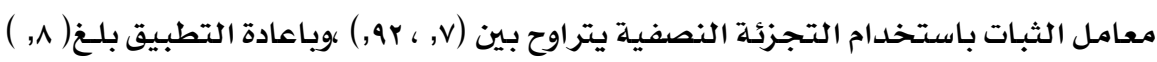
عندمايكون الفاصل الزمنى قصير.

$$
\text { تصحيح الاختبار: }
$$

يحصل المفحوص على درجة واحلدة عن ككل اجابـة صـحيحة .وبـذلك تكون الدرجـة الكليـة

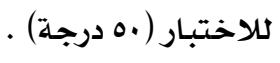

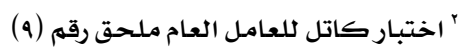




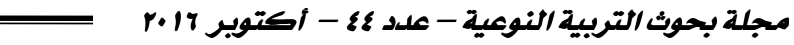

خامساً: اختبار القدرة على تقدير الأحجام :ץ "مأخوذ عن زينب عبد الحفيظ ، نجوى شكرى" ويقيس هذا الاختبار القدرة على اصدار أحكام صحيحلة تتعلق بالأبعاد ويتكون الاختبار مـن

ثلاثة مفردات

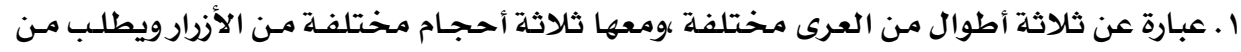

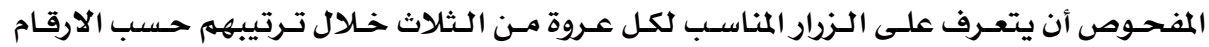

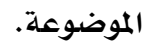

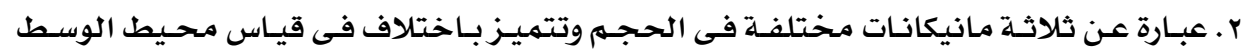

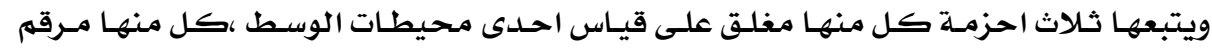

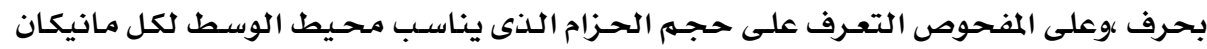

$$
\text { حسب الحروف المدونة. }
$$

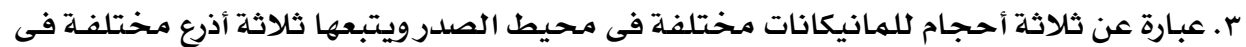

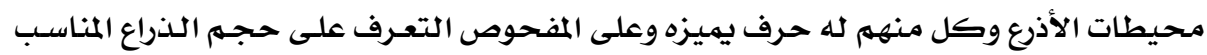

$$
\text { لحجم المانيكان حسب الحروف المدونة عليهم. }
$$

تصحيح الاختبار: تحسب درجـة واحدة لكل اجابـة صدحيحة ،أى أن الدرجـة الكليـة للاختبـار

عبارة عن تسـع درجات. سادساً: اختبار الإبتكار: 1 (للباحثة درجة) بهدف قياس الابتكار وهو مأخوذ عن اختبارات تورنس للتفكير الابتكارى ،ويتكون مـن ثلاثة

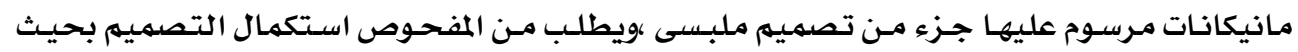

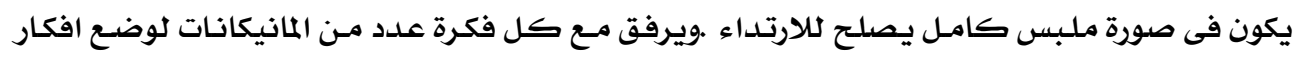
متنوعة يقيس من خلالها عناصرة ملكبس الابتكار: - - الطلاقة: ويقصد بها اعطاء عدد كبير من الافكار.

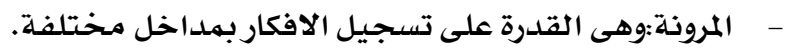

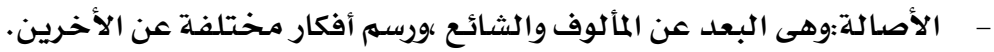
زمن الاختبار: الزمن المحدد لكل نموذج 10 دقيقة ،أى أن اجمالى زمن الاختبار هـ دقيقة.

$$
\text { تصحيح الاختبار: }
$$

الطلاقة : درجة على شكل تم رسمـه فى الزمن المحلدد.

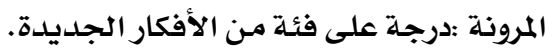

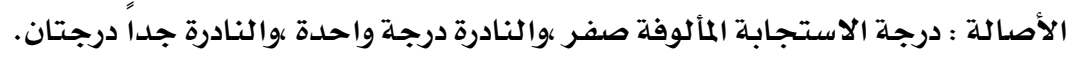

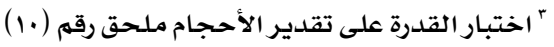
' اختبار الابتكار ملحق رقم (11) 


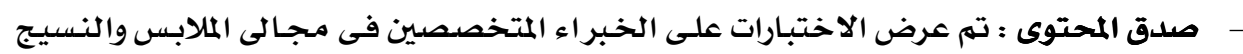

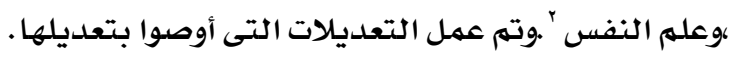

ثبات الاختبارات:

تم التأكد من ثبات الإختبارات باستخدام التجزئة النصفية ،ومعامل ألفا .والجدول التالى

يوضسح ذلك.

جدول رقم (r) ثبات الاختبارات

\begin{tabular}{|c|c|c|c|c|}
\hline \multicolumn{2}{|c|}{ معامل ألثا } & \multicolumn{2}{|c|}{ التجزئة النصفية } & \multirow{2}{*}{ ثبات الاختبارات } \\
\hline الدلالة & قيي الارتباط & الدلالة & قييم الارتباط & \\
\hline$\cdot, \cdot 1$ & •, マ৭६ & $\bullet,+1$ & $\cdot$, Arr - •, YOI & الأفكار المجردة \\
\hline$\bullet,+1$ & $\cdot, q \cdot V$ & $\cdot, \cdot 1$ & $\cdot$, Arr - •, $19 r$ & التذكر البصرى \\
\hline$\cdot, \cdot 1$ & $\cdot, \wedge \wedge 9$ & $\cdot, \cdot 1$ & $\cdot, 91 \vee-\bullet, \wedge \varepsilon \cdot$ & إدراك اللوز \\
\hline$\cdot,+1$ & $\cdot, \mathrm{Y} \leqslant \mathrm{r}$ & $\cdot, \cdot 1$ & $\bullet, \mathrm{V} \Delta-\bullet, \vee \bullet \bullet$ & اقصر الأطوال \\
\hline$\bullet,+1$ & $\cdot, 91 r$ & $\cdot,+1$ & $\cdot, 9 \leq r-\bullet, \wedge r r$ & تقدير الأحجام \\
\hline$\cdot,+1$ & $\cdot, \wedge \leqslant 0$ & $\bullet,+1$ & $\cdot, \wedge \vee q-\cdot, \wedge+1$ & الابتكار \\
\hline
\end{tabular}

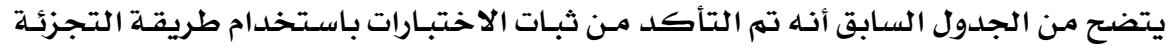

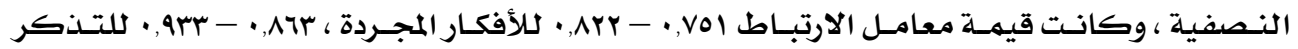

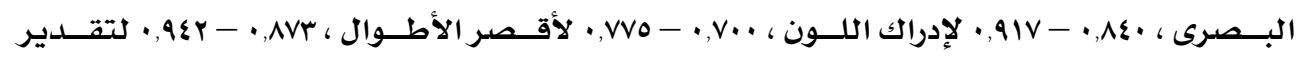

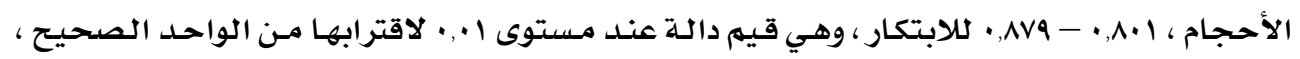

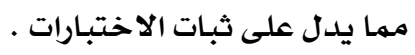

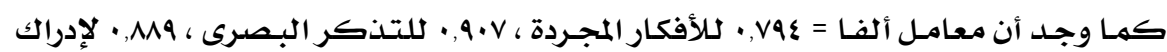

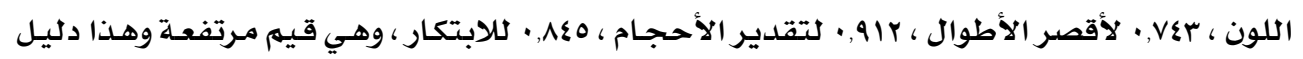

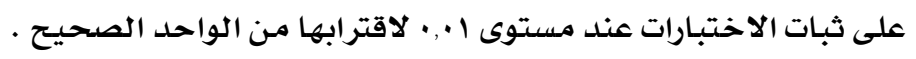
النتائج وهناقشتهات الاختبارات تتائج تحليل العمل:

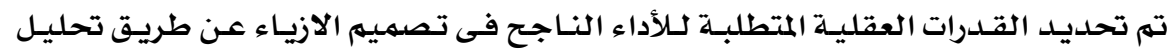

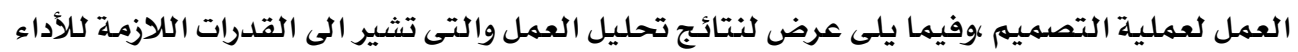

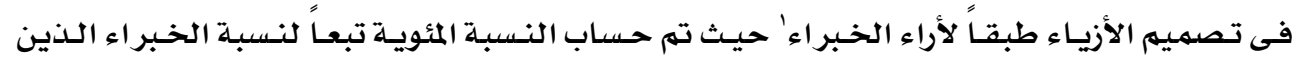

' اسماء السادة المحكمـين ملحق رقم (1) ' الخبر اء ملحق رقم ( ) 


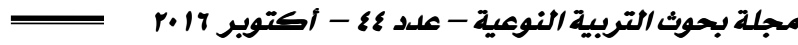

كانت درجـة موافقتهم (هام جـداً) واستبعدت الاستجابات الخاصـة ب (هـام) او (غير هـام) مـن تحديـ

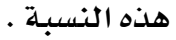

جدول رقم (ع) القدرات العقلية للأداء فى تصميم الازياء

\begin{tabular}{|c|c|c|}
\hline النسبة المئوية & التكرار & القدرات العقلية \\
\hline$\%$ & $\wedge$ & الابتكار \\
\hline$\%$ & $\wedge$ & الذكاء العام \\
\hline$\%$ & $\wedge$ & تقدير الاطوال \\
\hline$\%$ & $\wedge$ & تقدير الأحجام \\
\hline$\%$ Av,O & $\checkmark$ & التذكر البصرى \\
\hline$\%$ Yo & 7 & القدرة الادراكية \\
\hline$\% .7 r, 0$ & 0 & ذاكرة الأفكار المجردة \\
\hline$\%$ & $\varepsilon$ & التوافق الحركى \\
\hline$\%$. & $\varepsilon$ & المعالجة الذهنية للصور \\
\hline
\end{tabular}

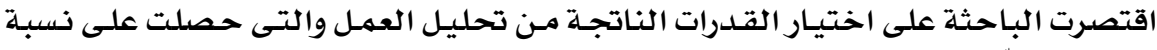

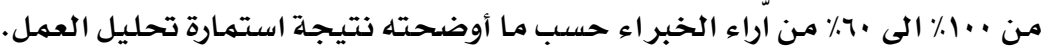
وبذلك تكون القدرات المتطلبة لعمليـة تصميم الأزياء هى :الابتكـار ،الدذكاء العـام ،القدرة

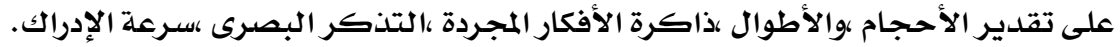
وتتفق نتائج تحليل العهـل مـع بعض الدراسـات السابقة منها دراسـة (عليه عابدين :

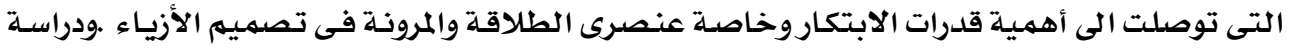

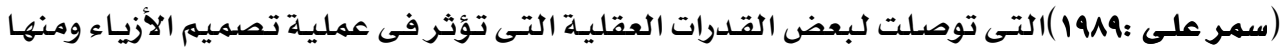

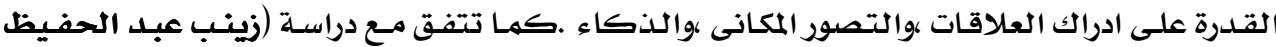

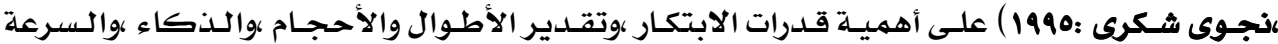

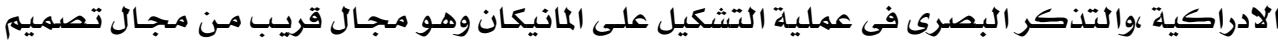
الأزياء.

• الفرض الأول : ينص الفرض الأول على " توجد فروق داله احصائيا بين متوسط درجات أفراد

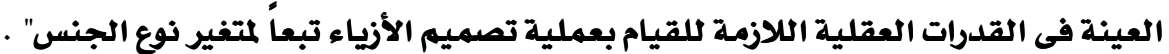
وللتحقق من هذا الفـرض تم تطبيق اختبـار "ت" لـدرجات أفراد العينـة ِِِ القدرات العقليـة

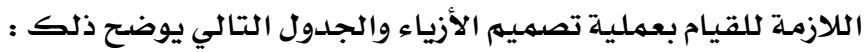


جدول رقم (ه) الفروق يْ متوسط درجات أفراد العينة يِ اختبارات القدرات العقلية تبعا لمتغير نوع الجنس

\begin{tabular}{|c|c|c|c|c|c|c|c|c|}
\hline \multicolumn{9}{|c|}{ درجة الحرية بع } \\
\hline \multirow[t]{2}{*}{ الدلالة } & \multirow{2}{*}{ 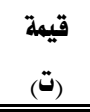 } & \multicolumn{2}{|c|}{ إناث ن= } & \multicolumn{2}{|c|}{ ذكور ن= } & \multirow{2}{*}{\multicolumn{2}{|c|}{ الاختبارات }} & \multirow[b]{2}{*}{ 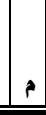 } \\
\hline & & | الانحراف المعيارى & المتوسط الحسابى & |الانحراف المعيارى & |المتوسط الحسابى & & & \\
\hline |دال عند ا., • لصالح الإذاث & $17, \cdot 7$. & $r, \cdot \cdot r$ & $\Delta 0, r \Delta 1$ & 1,799 & $r \varepsilon, 71 \Lambda$ & \multicolumn{2}{|c|}{ ذاكرة الأفكار المجردة } & 1 \\
\hline |دال عند •, • لصالح الإناث & $r, \bullet \Delta$ & $r, \cdot r$ & 15, rma & $1,77 \mathrm{~V}$ & $\Lambda, r+M$ & \multicolumn{2}{|c|}{ التذكر البصرى } & $r$ \\
\hline | دال عند ا., · لصالح الذكور & $r q, \Delta v$. & r,ATr & ITr, rYA & 0, ATr & 170, rA9 & \multicolumn{2}{|c|}{ السرعة الإدراكية } & $r$ \\
\hline |دال عند ••, · لصالح الذكور & 0,907 & $1, r \mathrm{rA}$ & 9,011 & $r, 711$ & $17,77 \%$ & \multicolumn{2}{|c|}{ الأشكال المتضمنة } & $\varepsilon$ \\
\hline |دال عند ه., · لصالح الإناث & $r, 07$. & $r, A Y M$ & $1 \cdot, \wedge q \vee$ & $1, r \cdot \xi$ & $\Lambda, 1 v 7$ & \multicolumn{2}{|c|}{ إدراك اللون } & 0 \\
\hline |دال عند ا., • لصالح الإذاث & $7, \varepsilon+1$ & r,qIV & $1 v, 7 \cdot 9$ & $1, \wedge \wedge \wedge$ & $11,7 \mathrm{rr}$ & \multicolumn{2}{|c|}{ تقدير الأطوال } & 7 \\
\hline |دال عند ا•, · لصالح الذكور & 9, rvo & r,११६ & 11,orq & $r, 17 \mathrm{r}$ & $r q, r v$. & \multicolumn{2}{|c|}{ كاتل للذكاء } & v \\
\hline |دال عند ه, • لصالح الإناث & $r, \cdot \psi \varepsilon$ & 1, ZYY & $v, 111$ & $\cdot, 901$ & $0, r \cdot \xi$ & \multicolumn{2}{|c|}{ تقدير الأحجام } & $\wedge$ \\
\hline |دال عند ا•, • لصالح الذكور & $0, r \wedge A$ & 1, ror & $v, 711$ & $r, \wedge \leqslant r$ & $\mid r, q \& r$ & الطلاقة & \multirow{3}{*}{ 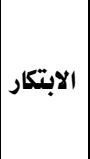 } & \\
\hline |دال عند ه, • لصالح الإناث & $r, 011$ & $1,0 \leqslant$ & $\{, \wedge \varepsilon \vee$ & •, AAV & $r, r+1$ & المرونة & & 9 \\
\hline دال عند ه., · لصالح الإثاث & $r, \cdots r$ & $1,07 \mathrm{~V}$ & $r, r \xi \gamma$ & • orr & $1,+r 1$ & الاصالة & & \\
\hline
\end{tabular}

يتضح من الجدول السابق أن قيمة (ت) كانت ( .7. .71 ) لإختبار الأفكار المجردة ،وهى قيمسة

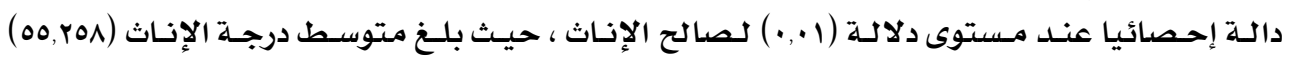

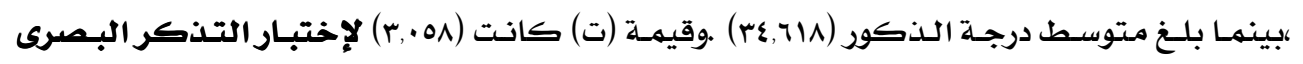

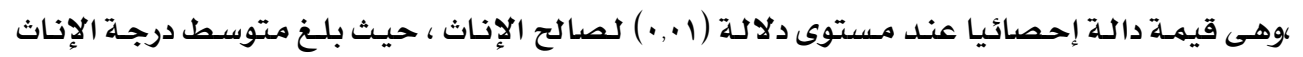

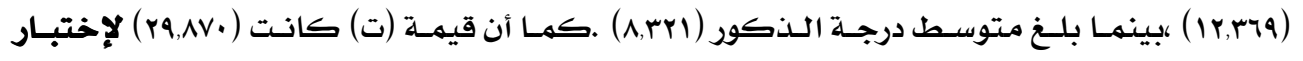

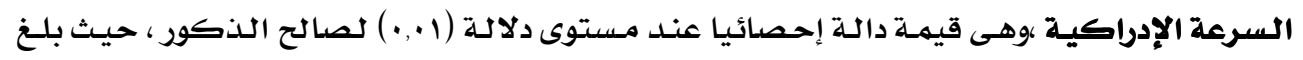

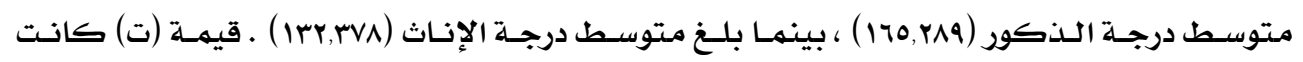

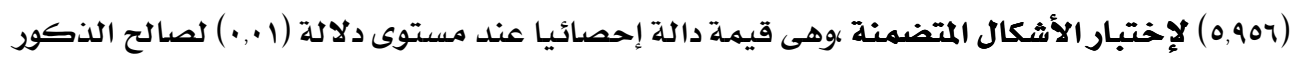

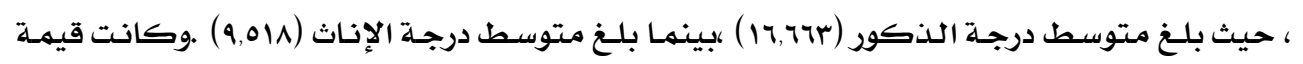

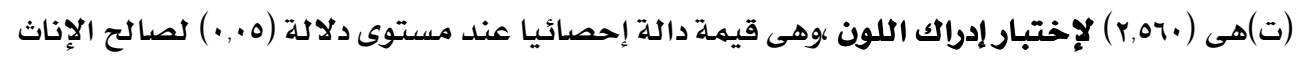

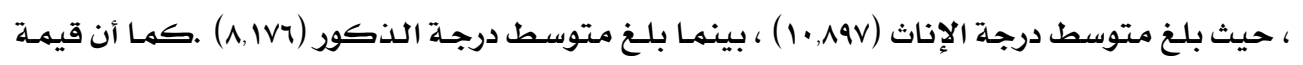

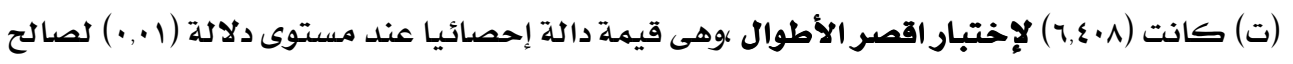

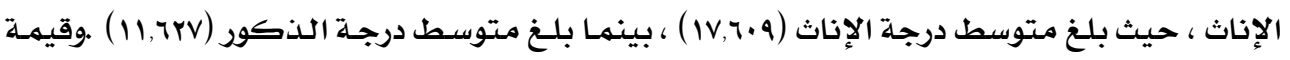

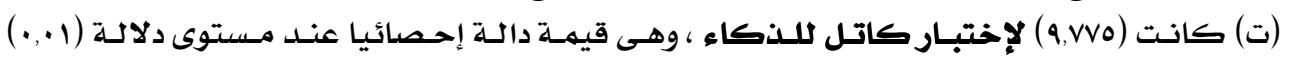

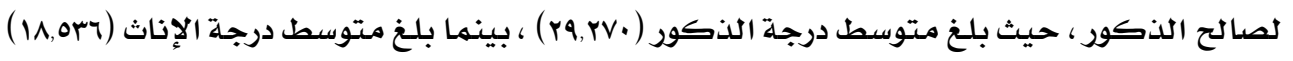

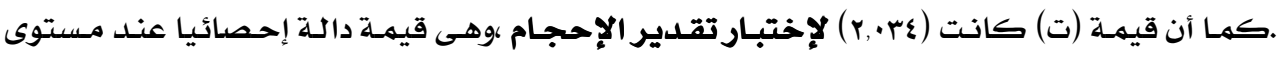

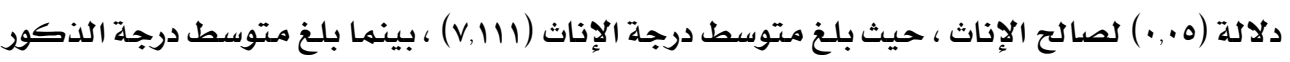




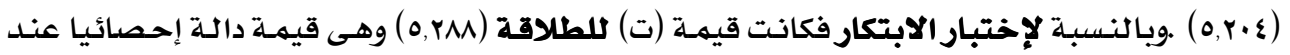

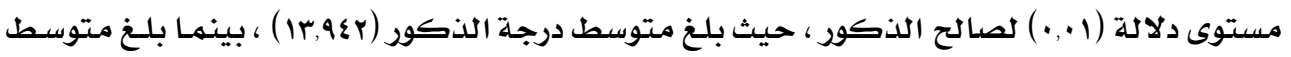

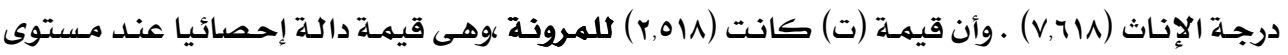

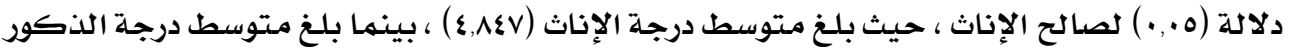

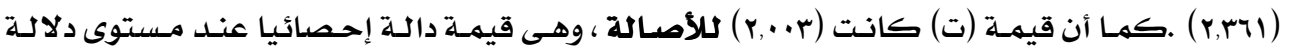

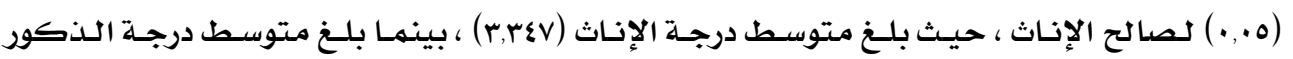

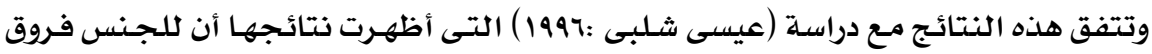

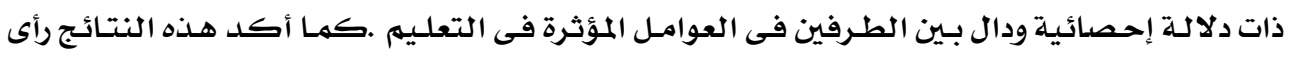

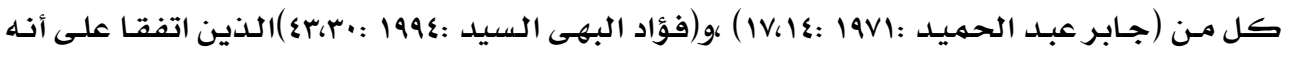

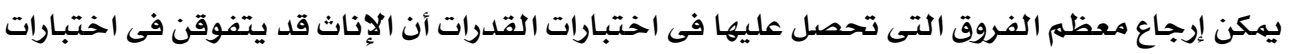

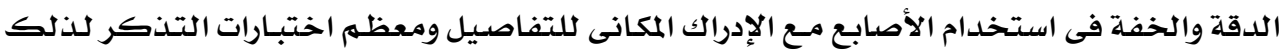

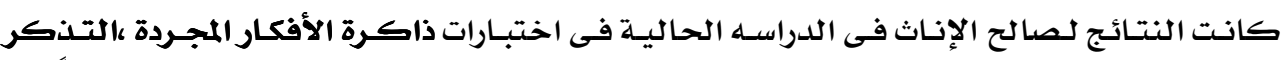

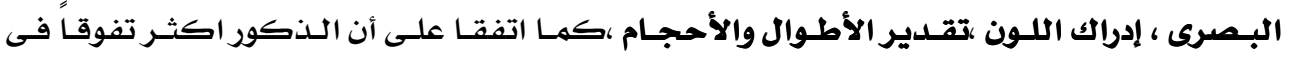

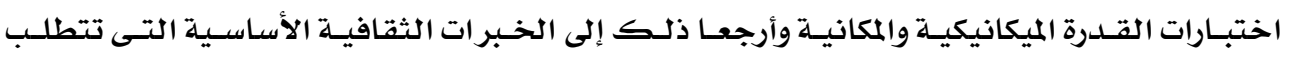

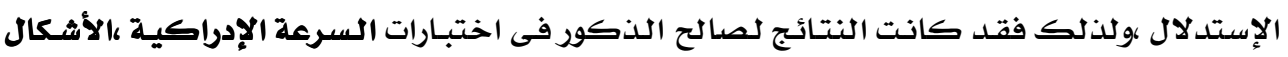

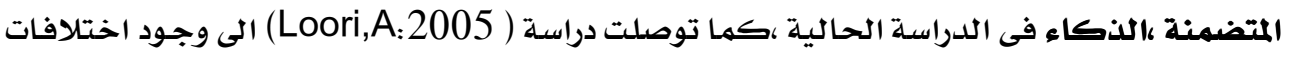

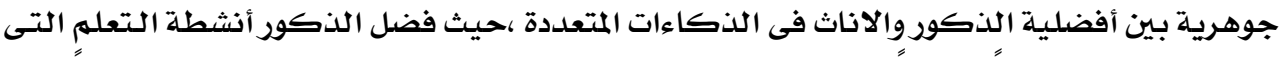

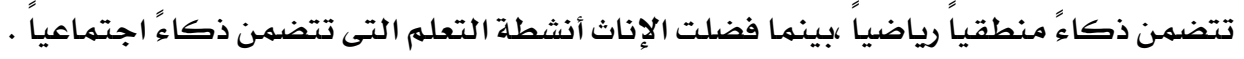

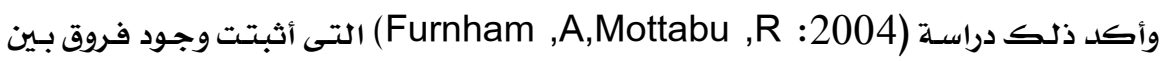

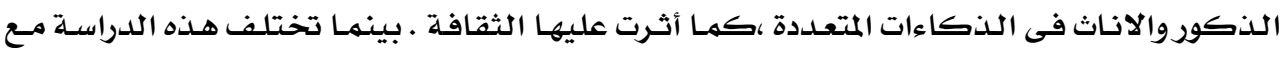

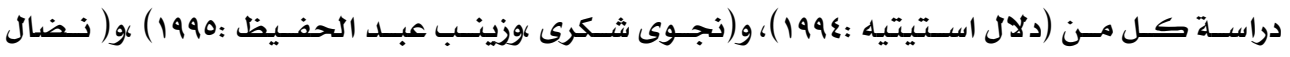

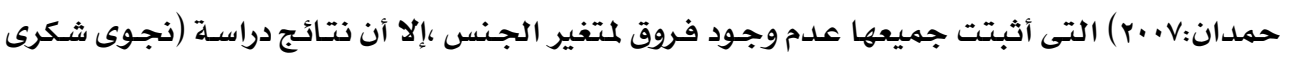

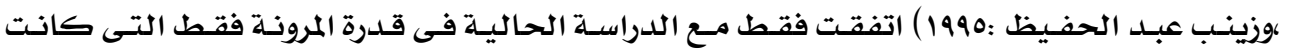

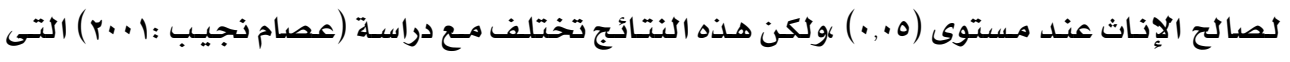

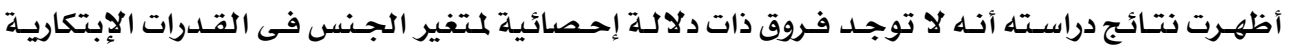

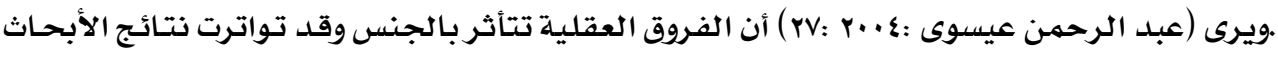

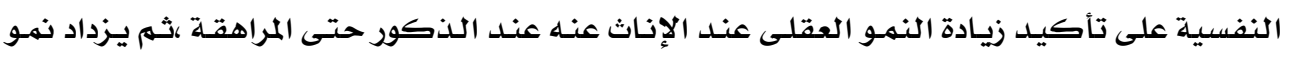

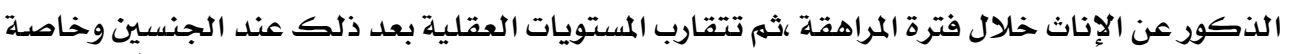

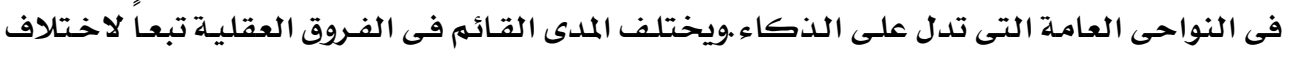

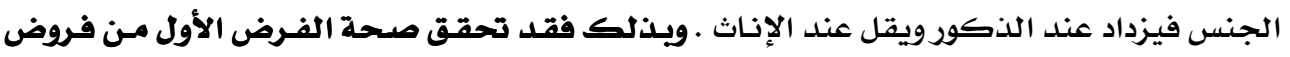


• الفرض الثانى : ينص الفرض الثانى على"توجد فروق داله احصائيا بين متوسط درجات أفراد

العينة فى القدرات العقلية الكلازمة للقيام بعملية تصميم الفيل الأزياء تبعاً لمتغير التعليم" .

وللتحقق من هذا الفـرض تم تطبيق اختبـار "ت" لـدرجات أفراد العينـة يِّ القـدرات العقليـة

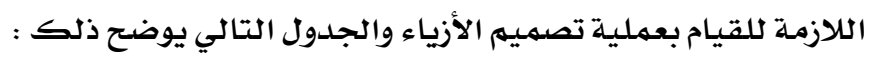

جدول رقم (ج) الفروق يْ متوسط درجات أفراد العينة ـِّ اختبارات القدرات العقلية تبعا لمتغير التعليم درجة الحرية مانع

\begin{tabular}{|c|c|c|c|c|c|c|c|c|}
\hline \multirow[b]{2}{*}{ الدلالة } & \multirow{2}{*}{ 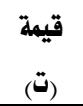 } & \multicolumn{2}{|c|}{ ثانوى فنى ن= } & \multicolumn{2}{|c|}{ ثانوى عام ن= } & \multirow{2}{*}{\multicolumn{2}{|c|}{ الاختبارات }} & \multirow[b]{2}{*}{ ค } \\
\hline & & الانحراف المعيارى & المتوسط الحسابى & الانحراف المعيارى & |المتوسط الحسابى & & & \\
\hline دال عند ا•,• لصالح العام & $10, r 79$ & 1,709 & $r \cdot, r o r$ & r,OAI & $\{q, r Y \wedge$ & \multicolumn{2}{|c|}{ ذاكرة الأفكار المجردة } & 1 \\
\hline دال عند ا•,• لصالح العام & $\xi, \bullet \xi \wedge$ & 1,rrr & $7,9 \wedge r$ & $r, 0 \leqslant q$ & $11, \llbracket \llbracket \varepsilon$ & \multicolumn{2}{|c|}{ التذكر البصرى } & r \\
\hline دال عند ا+,• لصالح العام & ro, $71 r$ & r,rrA & $11 \cdot$, rro & $\xi, r 70$ & $1 T \Lambda, 7 \leqslant$. & \multicolumn{2}{|c|}{ السرعة الإدراكية } & $r$ \\
\hline دال عند ا+,• لصالح العام & $0, \eta \wedge \uparrow$ & 1,701 & $1 \cdot, \cdot 1 r$ & $r, \wedge \leqslant \wedge$ & $10,90 \mathrm{r}$ & \multicolumn{2}{|c|}{ الأشكال المتضمنة } & $\xi$ \\
\hline دال عند ا+,• لصالح العام & $r, \cdot 1 r$ & 1,rrT & $\Lambda, \cdots \wedge$ & $r, . \Delta r$ & 11,111 & \multicolumn{2}{|c|}{ إدراك اللوز } & 0 \\
\hline دال عند ا+,• لصالح الفنى & 7,119 & $r, Y \xi V$ & 17,789 & r,Q Q & $9, \Lambda \cdot r$ & \multicolumn{2}{|c|}{ تقدير الأطوال } & 7 \\
\hline دال عند ا+,• لصالح العام & $0,7 v v$ & r, rOA & $r \cdot, \cdot r r$ & r,|हाY & $r 9,019$ & \multicolumn{2}{|c|}{ كاتل للذكاء } & v \\
\hline دال عند ه.,• لصالح الفنى & $r, r \xi Y$ & r, rqq & $\Lambda, \cdot 9 \varepsilon$ & 1,rro & 7,111 & \multicolumn{2}{|c|}{ تقدير الأحجام } & $\wedge$ \\
\hline دال عند ا+,• لصالح الفنى & $\xi, \xi 1 \wedge$ & $r, 71$. & 17,909 & 1,090 & 1,701 & الطلاقة & \multirow{3}{*}{ الابتكار } & \multirow{3}{*}{9} \\
\hline دال عند ○.,• لصالح الفنى & $r, A l l$ & Y, $\{\wedge 0$ & 0,70 & I, rrA & $r, \cdot 1 \varepsilon$ & المرونة & & \\
\hline دال عند ه., • لصالح العام & $r, \bullet r$ & $\cdot, \wedge \vee \varepsilon$ & $1, r \cdot r$ & $1,07$. & r, $า 7 r$ & الاصالة & & \\
\hline
\end{tabular}

يتضح من الجدول السابق أن قيمة (ت) كانت (10,179) لإختبار الأفكار المجردة ،وهى قيمسة

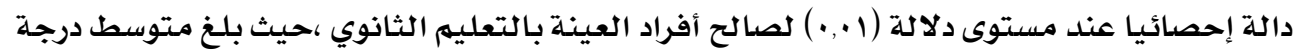

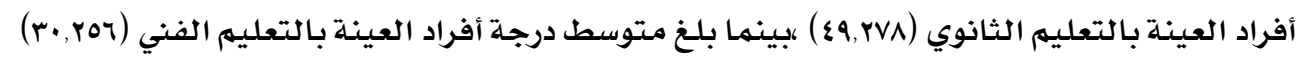

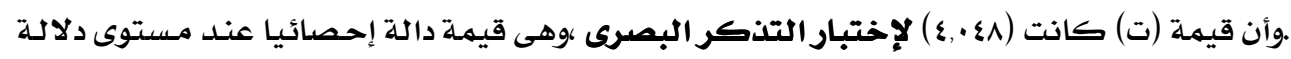

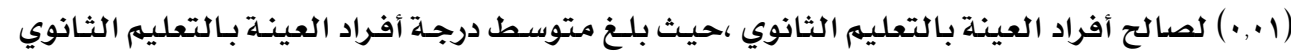

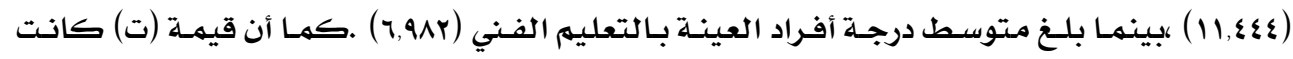

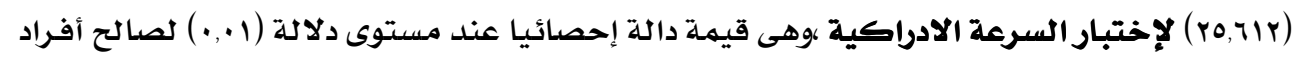

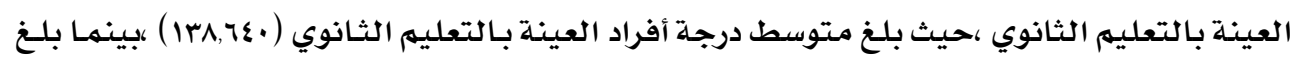

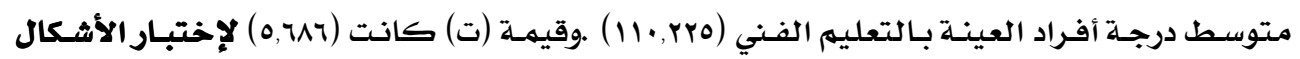

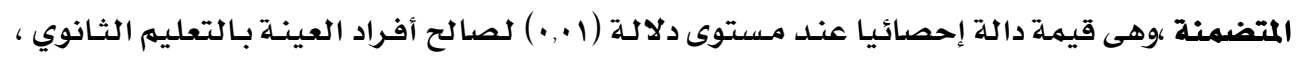

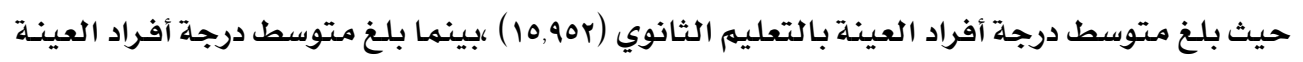

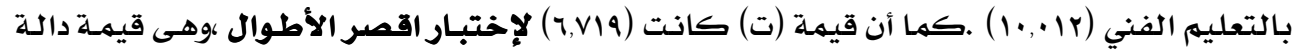

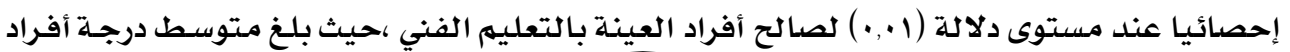




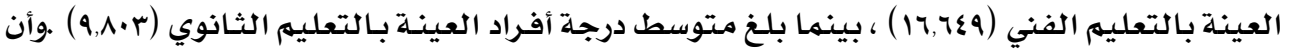

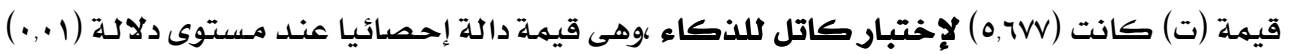

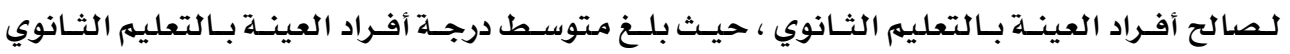

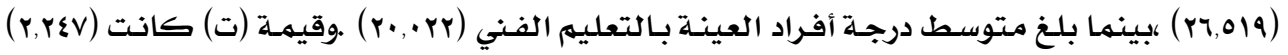

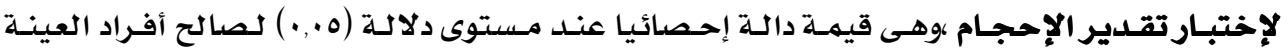

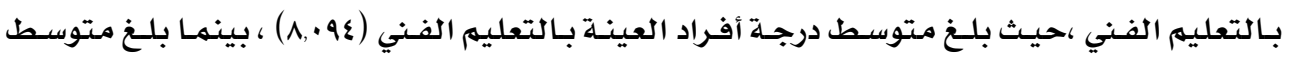

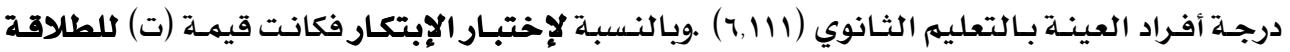

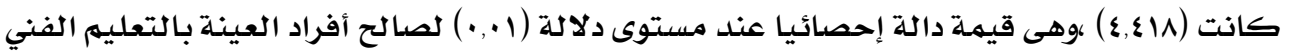

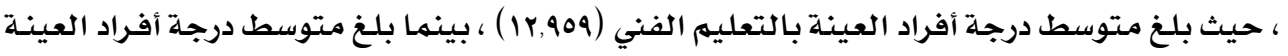

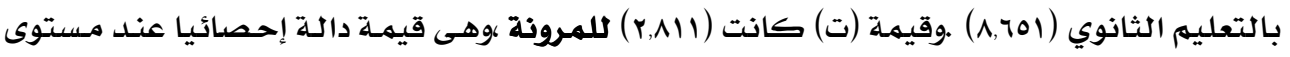

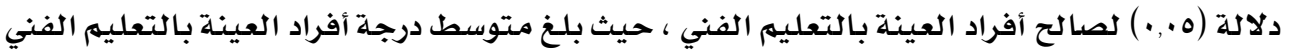

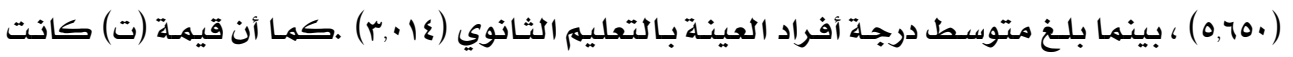

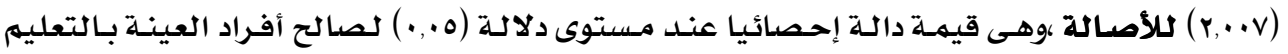

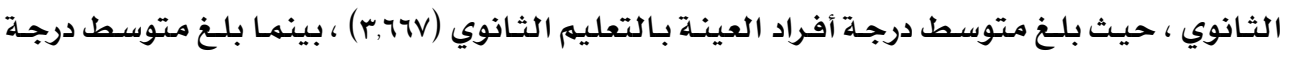

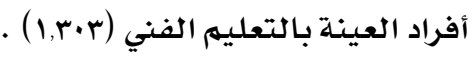

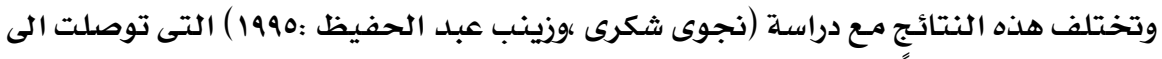

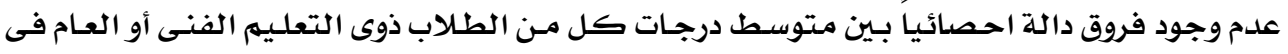

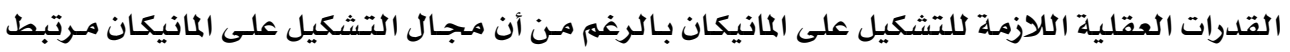

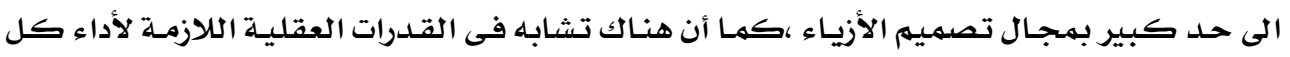

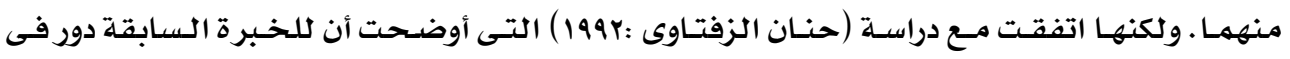

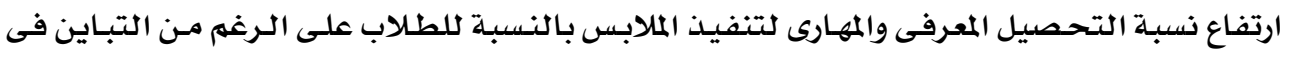

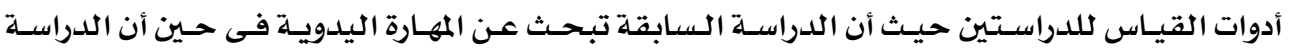

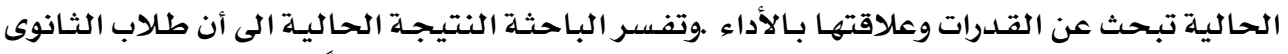

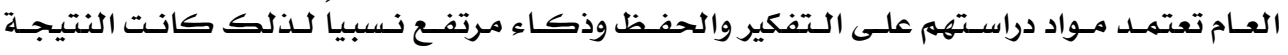

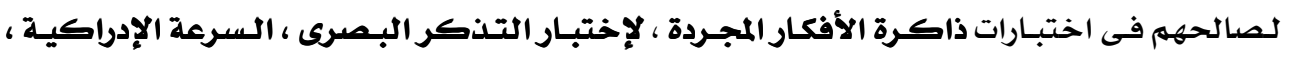

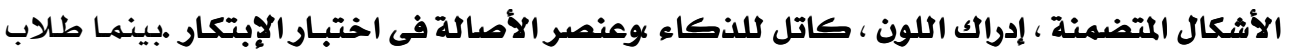

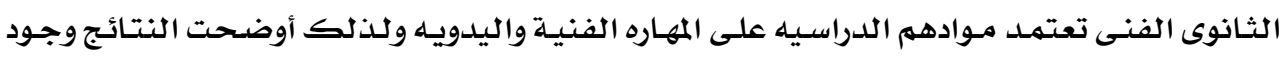

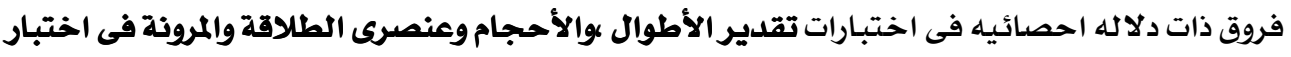

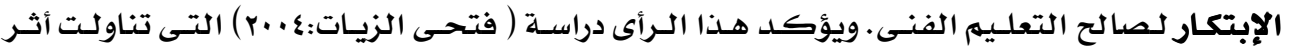

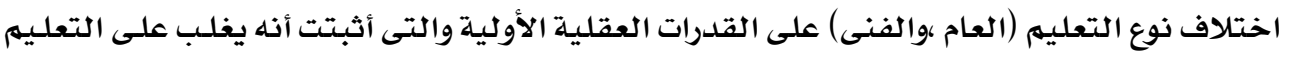

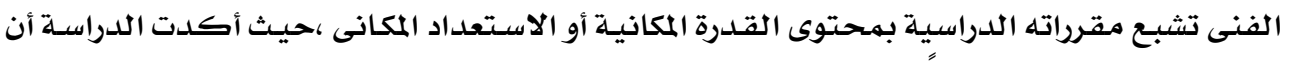

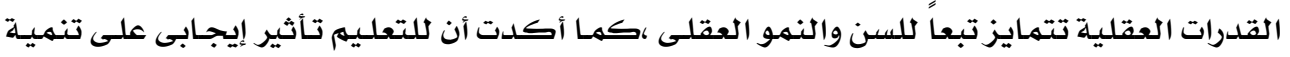


القدرات العقلية الأولية ،والقدرة العقلية العامة تتباين بتباين محتوى هذا التعليهم ومستواه. وبذلك فقد تحقق صحة الفرض الثانى من فروض البحث. التتوصيات :

وتوصى الباحثة فى ضوء نتائج البحث بما يلى :

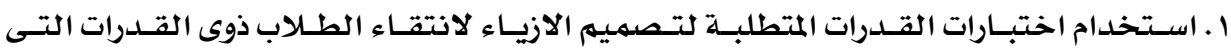

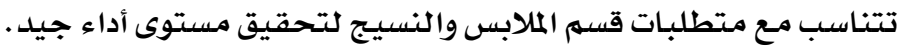

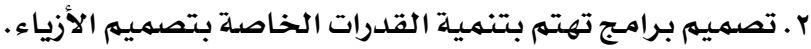

r. إجراء دراسات عن القدرات العقلية المتطلبة لمواد التخصص التهد الأخرى بقسهم الملابس والنسيج.

المراجع:

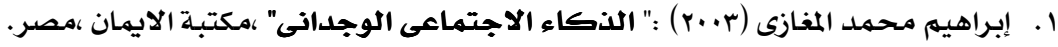

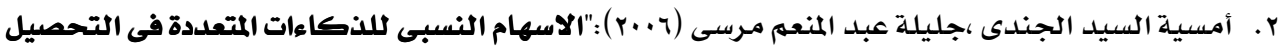

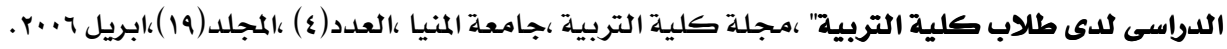

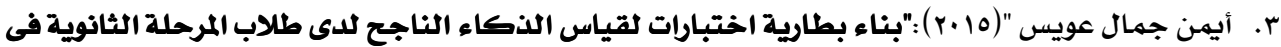

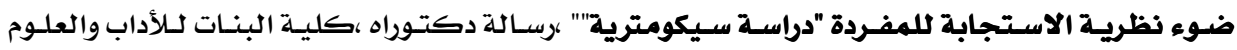

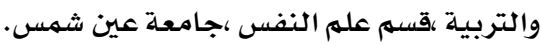

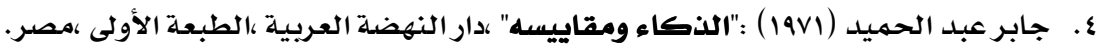

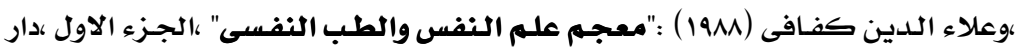

النهضة العربية ،القاهرة.

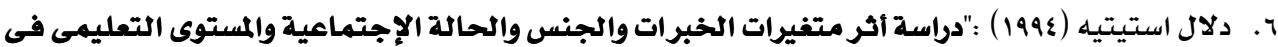

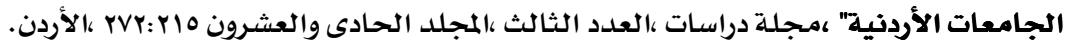

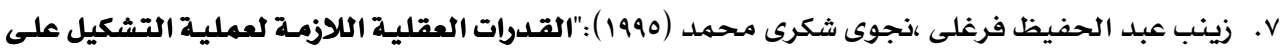

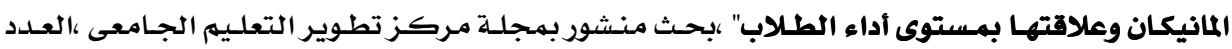

" (199 ) :"قيـاس القـدرات الذهنيـة المتطلبـة لإعـداد المانيكـان" ،بحـث منـشور

الثانى ،جامعة عين شمس.

، الجمعية المصرية للإقتصاد المنزلى ،جامعة المنوفية ،يناير.

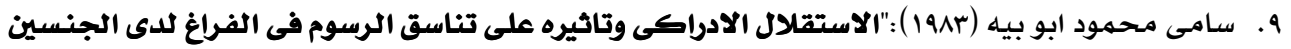

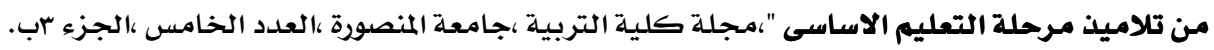

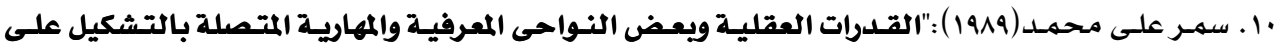

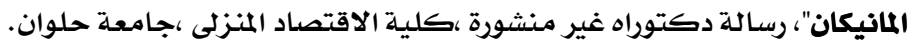

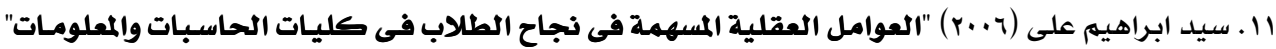

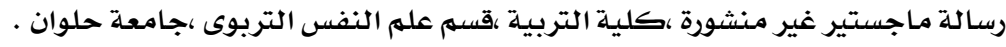

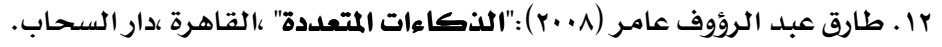




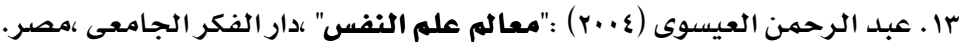

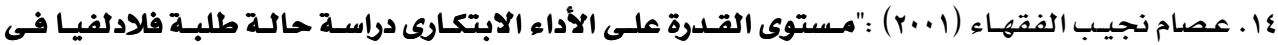
الأردن"،مجلة اتحاد الطلبة الجامعات العربية ،العدد التاسع والثلاثون ،المجلد الأول ،الأردن.

10 ـ عطية محمود (1909) :"التوجيه التربوى والمهنى " ،دار النهضة المصرية ،القاهرة. 17 . علية عابدين (19V1) :"دور التفكير الابتكارى فى تصميم الازيـاء" ،دكتوراة غير منشورة ،كليـة الاقتصساد المنزلى ،جامعة حلوان.

IV . عيسى شلبى (1997) : "العوامل المؤثرة فى التحصيل الأكاديمى للطالب" ،مجلة اتحاد الطلبة الجامعـات

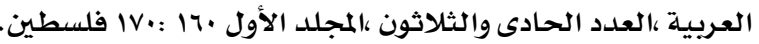

1 ـ فتحى مصطفى الزيات (ع + ب ):"أثر اختلاف نوع التعليم على تنمية القدرات العقلية للى عينة من طلاب التعليم العام والفنى" ،مجلة عله النفس المعرفى ،العدد الأول ،المجلد الأول ،مصر. (19VV) :"إعداد بطارية لقياس القدرات العقلية اللازمهة للنجاح فى الدراسة

بكليات الطب دراسة ميدانية" ،مجلة كلية التربية المنصورة ،العدد الثامن ،المجلد الثانى ،مصر.

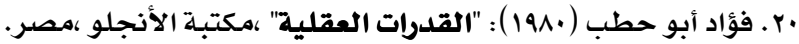
(1994) ) "القدرات العقلية" ،طه ،مكتبـة الانجلو المصرية ،القاهرة. .1

بr. فؤاد البهى السيد (·199) : "علم النفس العام" ،الطبعة الثالثة ،مكتبـة غريب ،مصر. (1901) :"القدرة العددية" ،دار الفكر العربى ،القاهرة. rr

(199£) :"الذكاء" ،دار الفكر العربى ،الطبعة الثالثة ،القاهرة ،مصر. re

ه . كفاية سليمان ، نجوى شكري ، س99 1 : " تصميم الأزياء والتشكيل علي المانيكان" دار الفكر العربي ، القاهرة جr. محممود عبد القادر (rا19 ) :"دراسة تجريبية للعوامل التى تتضمنها القدرة الميكانيكية" ،رسـالة ماجستير غير منشورة ،كلية الأداب جامعة عين شمس ،القاهرة.

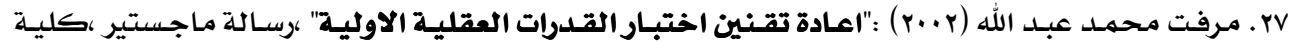
التربية ،جامعة حلوان.

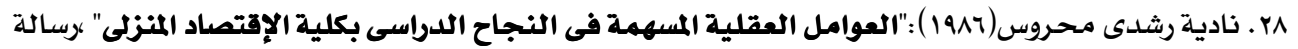
دكتوراه غير منشورة ،كلية التربية ،جامعـة حلوان.

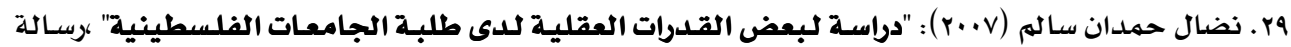
ماجستير،كلية التربية ،قسهم علهم النفس ،الجامعة الاسلامية ،غزة.

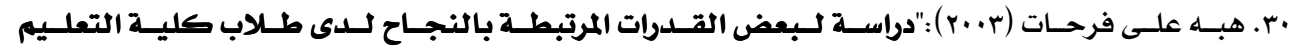
الصناعى"،رسالة ماجستير ،كلية التربية ،جامعة قناة السويس.

31-Furnham , A , Mottabu ,R(2004):"Sex and Culture differences in the estimates of general and multiple intelligences: A study comparing British and Egyptian student". Individual Differences Research Vol. 2, No.2, pp 82:96. Discovery.ucl.ac.uk/14/8808. 
32-Gardener, Howard (1993):"Frames of Mind, The Theory Of Multiple Intelligence", second Edition New York, Basic Book.

33- Loori, A (2005): "Multiple Intelligences :A comparative study between the preferences of males and females" Journal of social behavior and personality ,Vol 33 , No 1 ,p77

34- Marry, kofen ,( 1981): “ individuality in clothing selection and personal appearance $\left(3^{\text {rd }}\right)$ ", , collier Macmillan publishers, new York.

30- Oxendin joseph( 2001):" The Effect of Mental and physical practical on the learning of three motor skills", R. Q, Vol 40, pp. 755-763,.

35- Susan, geringer, (1986) :" fashion , color , line , and design “, third edition , glonoce publishing, company, division, of Macmillan, Inc.

36- Witkin ,H.A.(1965):"Psychological differentiation and forms of Pathology" Journal of Abnormal Psychology Vol.70 